\title{
Black carbon measurements in the boundary layer over western and northern Europe
}

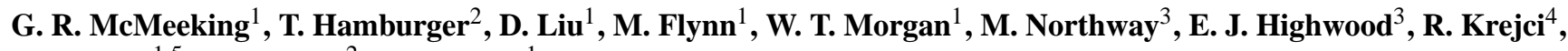 \\ J. D. Allan ${ }^{1,5}$, A. Minikin ${ }^{2}$, and H. Coe ${ }^{1}$ \\ ${ }^{1}$ Centre for Atmospheric Science, University of Manchester, Manchester, UK \\ ${ }^{2}$ Deutsches Zentrum für Luft- und Raumfahrt, Oberpfaffenhofen, Weßling, Germany \\ ${ }^{3}$ Department of Meteorology, University of Reading, Reading, UK \\ ${ }^{4}$ Department of Applied Environmental Science, Atmospheric Science Unit, Stockholm University, Sweden \\ ${ }^{5}$ National Centre for Atmospheric Science, University of Manchester, Manchester, UK
}

Received: 19 May 2010 - Published in Atmos. Chem. Phys. Discuss.: 4 June 2010

Revised: 29 August 2010 - Accepted: 1 September 2010 - Published: 6 October 2010

\begin{abstract}
Europe is a densely populated region that is a significant global source of black carbon (BC) aerosol, but there is a lack of information regarding the physical properties and spatial/vertical distribution of $\mathrm{rBC}$ in the region. We present the first aircraft observations of sub-micron refractory $\mathrm{BC}(\mathrm{rBC})$ aerosol concentrations and physical properties measured by a single particle soot photometer (SP2) in the lower troposphere over Europe. The observations spanned a region roughly bounded by $50^{\circ}$ to $60^{\circ} \mathrm{N}$ and from $15^{\circ} \mathrm{W}$ to $30^{\circ} \mathrm{E}$. The measurements, made between April and September 2008, showed that average rBC mass concentrations ranged from about $300 \mathrm{ng} \mathrm{m}^{-3}$ near urban areas to approximately $50 \mathrm{ng} \mathrm{m}^{-3}$ in remote continental regions, lower than previous surface-based measurements. $\mathrm{rBC}$ represented between 0.5 and $3 \%$ of the sub-micron aerosol mass. Black carbon mass size distributions were log-normally distributed and peaked at approximately $180 \mathrm{~nm}$, but shifted to smaller diameters $(\sim 160 \mathrm{~nm})$ near source regions. $\mathrm{rBC}$ was correlated with carbon monoxide (CO) but had different ratios to $\mathrm{CO}$ depending on location and air mass. Light absorption coefficients were measured by particle soot absorption photometers on two separate aircraft and showed similar geographic patterns to rBC mass measured by the SP2. We summarize the rBC and light absorption measurements as a function of longitude and air mass age and also provide profiles of rBC mass concentrations and size distribution statistics. Our results will help evaluate model-predicted regional rBC concentrations and properties and determine regional and global climate impacts from $\mathrm{rBC}$ due to atmospheric heating and surface dimming.
\end{abstract}

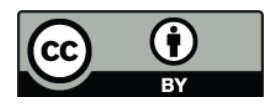

Correspondence to: G. R. McMeeking (gavin.mcmeeking@manchester.ac.uk)

\section{Introduction}

Black carbon (BC) aerosol emitted during incomplete combustion is the major light absorbing component of atmospheric aerosols and has important impacts on the atmosphere and climate. BC absorbs solar radiation, so it perturbs the radiative balance of the atmosphere on regional and global scales, leading to enhanced warming aloft and surface dimming (Jacobson, 2004; Ramanathan and Carmichael, 2008). Its concentrations are highest near source regions, resulting in "hotspots" of increased solar heating of the atmosphere, which may subsequently perturb the hydrologic cycle on regional scales (Ramanathan, 1981; Menon et al., 2002).

Investigations of the properties and concentrations of BC particles have been somewhat limited by measurement methods. Surface- and aircraft-based observations have relied on filter and/or optical based methods to measure BC. Both approaches suffer from low sensitivity and resolution (temporal and/or spatial) and both are also prone to a number of artefacts arising from the deposition of material to the filter (e.g., Kirchstetter et al., 2001; Weingartner et al., 2003; Chow et al., 2008). For example, filter-based absorption measurements require corrections for the additional absorption by particles of light scattered by filter fibres and deposited particles and the enhancement of absorption arising from organic coatings on sampled absorbing particles. Filter-based thermal optical measurements of organic (OC) and elemental carbon (EC) require an assessment of adsorption and/or volatility effects when sampling and depend on the operational protocol used to evaluate the sample (Watson et al., 2005). The low resolution and sensitivity of filter-based measurements is particularly problematic for aircraft studies, which often probe regions of low $\mathrm{BC}$ concentrations and that

Published by Copernicus Publications on behalf of the European Geosciences Union. 
feature rapid changes in concentrations and properties. They also provide no information regarding the size distribution or mixing state of the $\mathrm{BC}$ mass.

The development of the Single Particle Soot Photometer (SP2) provided the opportunity for the rapid, highly sensitive measurement of refractory $\mathrm{rBC}(\mathrm{rBC})$ concentrations, size distributions and mixing state (Stephens et al., 2003; Baumgardner et al., 2004; Schwarz et al., 2006). SP2 rBC mass measurements do not require that material be sampled to a filter and have been shown to be independent of the rBC mixing state (Slowik et al., 2007), avoiding many of the filterbased rBC measurement difficulties. The SP2 is a direct measurement of mass, so does not require an assumed mass absorption efficiency to convert an absorption measurement to mass concentration. Recent SP2 measurements have allowed for investigations of $\mathrm{rBC}$ impacts on atmospheric radiative processes (Gao et al., 2008; Shiraiwa et al., 2008; Schwarz et al., 2009) and new evaluations of models that include detailed microphysical schemes to predict $\mathrm{rBC}$ concentrations and mixing state (Koch et al., 2009; Vignati et al., 2010).

To date, SP2 observations in the troposphere have been limited to North America (Baumgardner et al., 2007; Schwarz et al., 2008a,b; Spackman et al., 2008; Subramanian et al., 2010), east Asia and the northern Pacific (Moteki et al., 2007; Shiraiwa et al., 2007, 2008; Baumgardner et al., 2008), and the Arctic (Jacob et al., 2009). Europe represented approximately $10 \%$ of global contained combustion rBC emissions in 1996 (Bond et al., 2004) and continues to be an $\mathrm{rBC}$ emissions hotspot, but the only previous SP2 observations in Europe were confined to the upper troposphere and lower stratosphere (Baumgardner et al., 2007). Previous non-SP2 rBC measurements in Europe have been primarily surface-based, resulting in low spatial-resolution information on the horizontal distribution of $\mathrm{rBC}$ and no information on its vertical distribution. Previous aircraft measurements in Europe relied on absorption techniques to estimate BC (Osborne et al., 2007; Petzold et al., 2007; Stohl et al., 2007), which are prone to artefacts, require an assumed conversion factor to obtain $\mathrm{BC}$ mass and are less sensitive than the SP2. The previous aircraft studies in Europe were also relatively isolated in their extent or examined specific meteorological conditions: Osborne et al. (2007) measured BC over the Po Valley in Italy and nearby portions of the Adriatic Sea and Petzold et al. (2007) and Stohl et al. (2007) examined biomass burning plumes transported from North America and pollution transported from Asia, respectively.

In order to improve the understanding of $\mathrm{rBC}$ mass concentrations and size distributions over Europe, we measured rBC using an SP2 on board the UK Facility for Airborne Atmospheric Measurements (FAAM) BAe-146 research aircraft during 21 research flights over Europe in 2008. We compared the SP2 observations to simultaneous measurements of aerosol light absorption coefficients $\left(b_{a p}\right)$ measured by particle soot absorption photometers (PSAP) on board the FAAM and DLR (Deutsches Zentrum für Luft-und Raum- fahrt) Falcon 20-E5 research aircraft. Here we describe the spatial and vertical distribution of $\mathrm{rBC}$ and aerosol absorption over Europe, compare rBC observations to other primary and secondary gas and aerosol-phase pollution tracers and compare $\mathrm{rBC}$ size distributions measured over Europe to those measured in other regions. We also provide an improved, size-resolved dataset for validating model estimates of $\mathrm{rBC}$ concentrations and distributions within Europe. Related papers examine $\mathrm{rBC}$ mixing state and ageing processes (McMeeking et al., 2010), aerosol composition and optical properties (Morgan et al., 2010a,b) and aerosol microphysical properties (Hamburger et al., 2010).

\section{Method}

We present results from two major aircraft measurement campaigns that took place in Europe between April and September 2008. The EUCAARI-LONGREX (European integrated Project on Aerosol Cloud Climate and Air Quality Interactions - Long Range Experiment, hereafter referred to as LONGREX) campaign, part of the broader EUCAARI project (Kulmala et al., 2009), occurred from 6-22 May 2008. It involved coordinated aircraft measurements of the aerosol and trace gas properties over northern and western Europe. The DLR Falcon research aircraft sampled aerosols and trace gases mainly in the free troposphere with periodic sampling of the boundary layer during profile descents and ascents. The DLR Falcon featured a downward pointing lidar (Esselborn et al., 2008) to characterise aerosol layers and identify regions of interest (Hamburger et al., 2010). The FAAM aircraft mainly sampled in the boundary layer, including the regions of interest identified by the DLR Falcon. The APPRAISE-ADIENT (Aerosol Properties, PRocesses AND InfluenceS on the Earth's climate - Appraising the aerosol Direct Impact on Climate, hereafter referred to as ADIENT) campaign took place over an approximately 1.5 year period, with operational periods in December 2007, April and September 2008, and May/June 2009 (here we only consider the April and September 2008 measurements). The LONGREX and ADIENT projects were complementary in that both sought to examine the effects of atmospheric ageing on aerosol optical properties and covered similar and in some cases identical geographic regions. The DLR Falcon only took part in the LONGREX campaign.

\subsection{Instruments on the DLR Falcon}

The DLR Falcon measured aerosol and trace gas concentrations and properties using a suite of remote sensing and in situ instruments. These included lidar measurements of aerosol profiles (Esselborn et al., 2008), in situ carbon monoxide $(\mathrm{CO})$ and ozone $\left(\mathrm{O}_{3}\right)$ measurements and measurements of aerosol size distributions using inboard and wing-mounted optical probes. The wing-mounted probes 
were a passive cavity aerosol spectrometer probe (PCASP100X) and a forward scattering spectrometer probe (FSSP300). Inside the cabin, two Grimm optical particle counters (Model Sky-OPC 1.129) also measured aerosol size distributions. A set of five condensation particle counters (CPC; Feldpausch et al. (2006)) and a thermodenuder $\left(250^{\circ} \mathrm{C}\right)$ measured number concentrations of volatile and non-volatile particles and a 3-wavelength PSAP (Virkkula et al., 2005) measured aerosol light absorption coefficients at $\lambda=467 \mathrm{~nm}, 530 \mathrm{~nm}$, and $660 \mathrm{~nm}$, which were corrected following Virkkula et al. (2005) and Virkkula (2010).

The absorption data were corrected using the parameterisation given by Virkkula et al. (2005). The size distribution data retrieved from the Grimm-OPC measurements were used to estimate the scattering coefficient used in the correction. The Grimm-OPC used for the scattering coefficient estimate was calibrated with ammonium sulphate $\left(\left(\mathrm{NH}_{4}\right)_{2}\right.$ $\mathrm{SO}_{4}$ ) particles and the scattering coefficient correction assumed the sampled aerosol had the same refractive index as ammonium sulphate $(1.53+0 i)$.

\subsection{Instruments on the FAAM aircraft}

Multiple instruments aboard the FAAM research aircraft provided detailed in situ chemical and physical measurements of aerosol and trace gas species and a number of remotely sensed products. Inboard aerosol instruments sampled ambient aerosol through stainless steel tubing connected to Rosemount inlets (Foltescu et al., 1995). Osborne et al. (2007) showed sub-micron particle losses through the inlets to be negligible.

A PSAP measured aerosol light absorption at $\lambda=567 \mathrm{~nm}$, adjusted to standard temperature and pressure (STP; temperature $=273.15 \mathrm{~K}$ and pressure $=1013.25 \mathrm{hPa}$ ). The PSAP data were corrected for spot size, flow rate, and the presence of scattering particles on the filter using the approach given by Bond et al. (1999) and clarified by Ogren (2010), where the scattering coefficient needed for the correction was taken from a TSI 3563 integrating nephelometer on the aircraft. The corrections do not account for enhancements in absorption due to the presence of organic films surrounding the filter fibres (Subramanian et al., 2007) or coating the preexisting absorbing particles in the filter (Cappa et al., 2008; Lack et al., 2008). Both effects probably increase with higher organic aerosol loadings. Black carbon aerosol number and mass concentrations were measured as a function of size using an SP2 (DMT Inc., Boulder, Colorado, USA), described in detail in the following section.

A compact Time-of-Flight aerosol mass spectrometer (AMS; Aerodyne Research Inc., Boston, MA, USA) measured sub-micron aerosol composition at approximately $30 \mathrm{~s}$ time resolution (Drewnick et al., 2005; Canagaratna et al., 2007). The FAAM aircraft AMS observations during the ADIENT and LONGREX campaigns are examined by Morgan et al. (2010a). Aerosol total and back-scattering coeffi- cients were measured by a 3-wavelength integrating nephelometer (TSI Inc., St. Paul, MN, USA). Scattering coefficients were corrected for truncation and non-lambertian light source errors using the sub-micron parameterisation provided by Anderson et al. (1996). Aerosol size distributions were measured by a wing-mounted PCASP-100X (Particle Measurement Systems, Boulder, CO, USA). The PCASP channel limits were determined experimentally using di-ethyl-hexyl-sebecate (DEHS) calibration particles and adjusted to a corresponding PSL-equivalent channel limit at a refractive index of 1.588 using Mie theory. PCASP volume size distributions were integrated below $0.9 \mu \mathrm{m}$ to obtain an estimate of total sub-micron volume concentrations. Sub-micron volume concentrations were multiplied by density estimated from AMS composition measurements following Cross et al. (2007).

Carbon monoxide was measured by an Aero-Laser AL5002 VUV resonance fluorescence gas analyser. In-flight $\mathrm{CO}$ calibrations were applied to the raw $\mathrm{CO}$ data. A surrogate for nitrogen oxides $\left(\mathrm{NO}_{\mathrm{x}}\right)$, operationally defined as any nitrogen species converted to NO under a heated molybdenum catalyst, was measured using a Thermo Scientific model 42 chemiluminescence gas analyser. The instrument interpreted other $\mathrm{NO}_{\mathrm{y}}$ species, such as nitric acid, as $\mathrm{NO}_{\mathrm{x}}$ using this definition (Steinbacher et al., 2007). Ozone was measured using a Thermo Scientific model 49 UV photometric gas analyser.

\subsection{The single particle soot photometer}

The SP2 relied on a patented laser induced incandescence technique to characterise the mass and concentration of individual rBC particles (Stephens et al., 2003). For simplicity we apply the term "refractory black carbon" to the incandescent material measured by the SP2, following previous SP2 studies. Bond and Bergstrom (2006) and Andreae and Gelencser (2006) discuss other nomenclature for BC. Even though neither study refers specifically to the material detected by the SP2, they provide useful information linking measurement methods and chemical/physical properties to the various terms applied in the literature. A particle sampled by the instrument is illuminated by an intra-cavity Nd:YAG laser $(\lambda=1064 \mathrm{~nm})$ with a Gaussian profile (TEM 00 mode). If it contains sufficient absorbing material, the particle is heated to its incandescence temperature and emits thermal radiation, which is measured by two optical detectors. The peak intensity of the detected radiation signal is related to the mass of absorbing material and is insensitive to particle morphology or mixing state (Slowik et al., 2007). Shiraiwa et al. (2008) and Schwarz et al. (2008b) have shown that the uncertainty in the determination of the mass of a single $\mathrm{rBC}$ particle is approximately $30 \%$, which corresponds to an uncertainty in diameter of approximately $10 \%$. The uncertainty partly arises from potential differences in the shape and morphology of ambient $\mathrm{rBC}$ and the calibration material, which 
leads to differences in the particle emissivity and incandescence signals (Shiraiwa et al., 2008; Moteki et al., 2010).

The SP2 incandescence response for each detector was calibrated by the manufacturer (DMT) by passing dried, differential mobility analyser-selected (DMA; TSI 3085, St. Paul, Minnesota, USA) monodisperse Aquadag carbon particles to the instrument (Aecheson Colloids Company, Port Huron, Michigan). The measured incandescence response was related to $\mathrm{rBC}$ mass calculated from the mobility diameter and an estimate of the effective density of the calibration particles. The manufacturer calibration obtained in this way relied on a constant density assumption for the Aquadag calibration material, however Moteki et al. (2010) showed that the effective density (the relationship between mobilityestimated volume and mass measured by an aerosol particle mass (APM) analyser (Ehara et al., 1996)) of Aquadag decreased linearly with mobility diameter. The size dependence arose from the behaviour of the non-spherical Aquadag particles in the DMA. We adjusted the calibration results to account for the shift and provide the calibration data in the supplementary information. Moteki et al. (2010) also showed that different $\mathrm{rBC}$ calibration materials produced different incandescence signal peak value-to-rBC mass relationships, with Aquadag having a larger signal response for a given $\mathrm{rBC}$ mass compared to ambient soot measured in Tokyo, Japan with an APM-SP2 system. The magnitude of the difference in responses was about $40 \%$ for particles below $10 \mathrm{fg}$ in mass $\left(0.22 \mu \mathrm{m}\right.$ in diameter assuming a density of $\left.1.8 \mathrm{~g} \mathrm{~cm}^{-3}\right)$, but the differences for larger particles were smaller. We have not attempted to adjust our results to account for these differences because it was not clear if ambient soot in Tokyo had similar properties to the ambient soot measured in the campaign.

Previously reported SP2 measurements used incandescence detectors with similar gain settings and optical filters to restrict the detected light to "broadband" (350-800 nm) and "narrowband" (630-800 nm) wavelength ranges. The set-up allows for classification of the incandescing material by its thermal emission spectrum using the ratio of the narrowband and broadband peak signals or colour ratio, as been done previously by, e.g., Schwarz et al. (2006). To date, ambient SP2 measurements have not identified a significant contribution by non-rBC absorbing aerosols to the incandescence signal (e.g., Schwarz et al., 2006; Subramanian et al., 2010). In this study, the gain settings on the incandescence detectors (photomultipliers), were optimized to maximize the dynamic range for particle sizing as opposed to retrieving colour ratios over the broadest range of particle sizes. The baseline of the detectors was also adjusted to provide a larger detection range for the September flights.

In addition to the incandescence detectors, two avalanche photodetectors (APD) measure light scattered by particles in the laser beam at $1064 \mathrm{~nm}$. One of the detectors is a fourelement APD that is used to determine the position of each particle as it passes through the laser beam (Gao et al., 2007).
This information is used to fit Gaussian functions to particles that either saturate the detector or contain $\mathrm{rBC}$, which causes the particle to evaporate when heated by the laser and leads to a degradation of the scattering signal. The scattered light signals provide concentration and sizing information for nonincandescing particles in the size range $D_{p}=150-600 \mathrm{~nm}$. Scattered-light data also allows investigations of the $\mathrm{rBC}$ mixing state, which we describe in a companion manuscript (McMeeking et al., 2010). The scattering detectors were calibrated using dried polystyrene latex spheres (PSL) by relating the detector response to the physical PSL size. A subset of calibrations included a size-selection step using a DMA to remove sub- $100 \mathrm{~nm}$ particles thought to arise from atomization of surfactants and contaminants in the PSL solution. The size calibration holds for particles with the same refractive index as PSL (1.588), however estimates of the aerosol refractive index based on aerosol composition measured in the boundary layer by the AMS were within 5\% of the PSL value, so we have not adjusted the particle diameters to account for deviations from the refractive index of PSL. The SP2 was tested in the laboratory prior to each aircraft deployment to ensure alignment of the sample aerosol jet, laser and each detector as well as the shape of the laser beam. The consistency of the instrument alignment was checked during deployments using PSL test particles and examination of the beam shape.

The range of particle masses detected by the SP2 depends on the detector gain settings and the laser power incident on the rBC particle (Schwarz et al., 2010). Schwarz et al. (2010) found that not all $\mathrm{rBC}$ particles were brought to their vaporisation temperature below a certain laser intensity threshold, invalidating their mass determination. $\mathrm{rBC}$ particles with less mass required higher threshold laser intensities to ensure they reached their vaporisation temperature. We used the manufacturer's smallest resolved Aquadag mass signal from their calibration to determine the lower mass detection limit of the instrument of $0.2 \mathrm{fg}$ (70 $\mathrm{nm}$ mobility diameter and estimated Aquadag effective density of $0.8 \mathrm{~g} \mathrm{~cm}^{-3}$; Moteki, 2010). This value was approximately a factor of four lower than the typical $\mathrm{rBC}$ mass detection limits of $0.7-1 \mathrm{fg}$ reported for the SP2 (Shiraiwa et al., 2008; Schwarz et al., 2010; Subramanian et al., 2010) and the detection efficiency of the SP2 as configured in this study probably dropped below unity for masses below at least $0.7 \mathrm{fg}$ based on Schwarz et al. (2010). The upper mass limit of the instrument was taken to be the mass of the largest calibration point available or $60 \mathrm{fg}$ (550 nm; Aquadag density 0.6; Moteki and Kondo, 2010).

The mass detection range for the SP2 in this configuration $(0.2-60 \mathrm{fg})$ translates to a volume equivalent diameter of 55$400 \mathrm{~nm}$ for an assumed $\mathrm{rBC}$ void-free density of $1.8 \mathrm{~g} \mathrm{~cm}^{-3}$ (Bond and Bergstrom, 2006; Cross et al., 2007). Unfortunately we were unable to diagnose whether the instrument was operating at a sufficient laser intensity for the broadest possible detection region following the recommendations of 

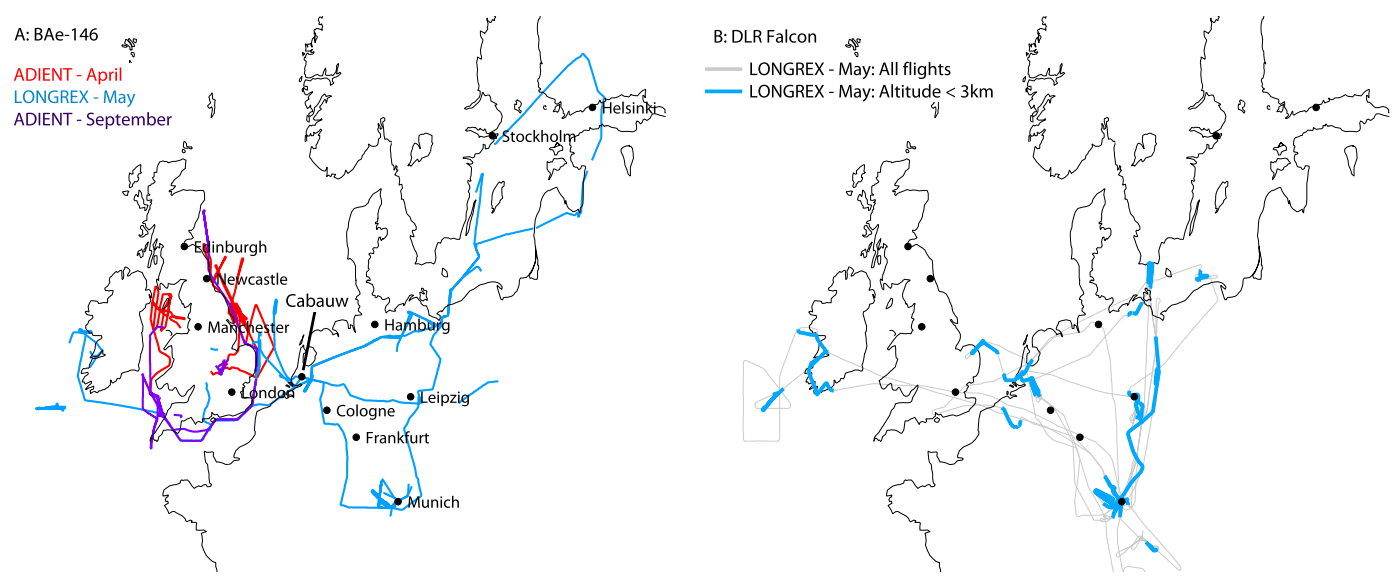

Fig. 1. Map showing flight tracks (restricted to altitudes below $3 \mathrm{~km}$ ) during the April and September 2008 ADIENT and May 2008 EUCAARI-LONGREX measurement periods for the FAAM BAe-146 research aircraft and flight tracks during May 2008 for the DLR Falcon research aircraft. Portions of the DLR Falcon flight tracks falling below $3 \mathrm{~km}$ are indicated.

Schwarz et al. (2010). They recommend regular testing of the laser power by examining the colour ratio distribution at different laser intensities to identify the "threshold intensity for proper detection" and operating at intensities above that value. We note that any reductions in the laser power would result in an underestimate of the smallest $\mathrm{rBC}$ core diameters which only have a minor contribution to total $\mathrm{rBC}$ mass in this study.

A problem related to pressure-dependent flow control in the instrument resulted in unreliable data for large portions of the LONGREX flights at altitudes above approximately $2 \mathrm{~km}$. During these periods the SP2-measured rBC and nonrBC aerosol concentrations dropped by an order of magnitude or more relative to other aerosol data (e.g., AMS aerosol mass, PCASP aerosol volume, PSAP absorption coefficients). These periods were removed from the data and were identified by comparing the SP2 scattering concentrations to the PCASP and nephelometer signals. All data reported here have been carefully quality assured by comparison with the other instruments aboard the aircraft to ensure their validity. We discuss the processing procedures for the SP2 data, including the use of both incandescence detectors to determine the rBC size distribution, in the supplementary information.

\section{Results}

The data presented here were obtained from 21 FAAM aircraft flights and 12 DLR Falcon flights over the UK and Europe that spanned a geographic range from approximately $15^{\circ} \mathrm{W}$ to $30^{\circ} \mathrm{E}$ and from $50^{\circ}$ to $60^{\circ} \mathrm{N}$. The LONGREX and ADIENT FAAM aircraft flights represent approximately $85 \mathrm{~h}$ of flight time, but only 36 hours of SP2 data due to the instrument response problem at higher altitudes. We averaged all FAAM aircraft observations over each straight and level flight run (SLR) and we separated them into sub-3 km altitude SLRs (within the boundary layer) and above $3 \mathrm{~km}$ SLRs (above the boundary layer), following Morgan et al. (2010a) and Hamburger et al. (2010). DLR Falcon data were averaged for periods when the aircraft was in the boundary layer $(<3 \mathrm{~km})$. Unless otherwise noted, we use the term SLR to refer to sub-3 km SLRs throughout the manuscript. All particle mass concentrations are reported in mass per volume of air at standard temperature and pressure (denoted $\mathrm{s} \mathrm{m}^{-3}$; temperature $=273.15 \mathrm{~K}$ and pressure $=1013.25 \mathrm{hPa}$ ).

\subsection{Overview of the flying campaigns}

The majority of LONGREX and ADIENT research flights took place during clear sky conditions. Table 1 and Fig. 1 provide details for the individual flights. Maps showing the $850 \mathrm{hPa}$ geopotential height and wind fields for 12:00 UTC together with flight tracks for each measurement day are included in the supplementary material. The meteorological conditions for LONGREX flights were less variable compared to ADIENT flights, due to the large number of flights during a relatively short period flown during LONGREX. Conditions during the first week of the LONGREX measurement period were dominated by a strong, anti-cyclonic system centred approximately over Denmark, illustrated in Fig. 2. The position of the anti-cyclone caused easterly flow over most of Europe and strong subsidence over the region. All but two of the LONGREX flights occurred during the high-pressure dominated period. The remaining LONGREX flights took place in building high pressure after passage of a weak frontal system, which featured a large-scale flow pattern similar to the earlier LONGREX flights. Hamburger et al. (2010) provide a detailed description of the meteorological conditions during LONGREX.

No meteorological overview of the ADIENT campaign is available, so we discuss the meteorological conditions here 
Table 1. Summary of FAAM aircraft flights (with valid SP2 data) during EUCAARI-LONGREX and APPRAISE-ADIENT campaigns and DLR Falcon flights during the EUCAARI-LONGREX campaign.

\begin{tabular}{llll}
\hline Date & FAAM ID & Falcon ID & Operating area \\
\hline 2 April 2008 & B355 & - & England east coast \\
10 April 2008 & B356 & - & England east coast \\
16 April 2008 & B357 & - & Welsh coast and Manchester/Liverpool plume \\
2 May 2008 & - & $080502 \mathrm{a}$ & Alps and northern Italy \\
6 May 2008 $(\mathrm{am})$ & B362 & - & Germany/Belgium and North Sea \\
6 May 2008 $(\mathrm{pm})$ & B363 & $080506 \mathrm{~b}$ & Germany/Belgium and North Sea \\
7 May 2008 & B364 & - & Southern Germany \\
8 May 2008 $(\mathrm{am})$ & B365 & $080508 \mathrm{a}$ & Germany/Poland and Baltic coast \\
8 May 2008 $(\mathrm{pm})$ & B366 & $080508 \mathrm{~b}$ & Germany/Netherlands/Belgium \\
9 May 2008 & B367 & - & Southern Germany (aircraft inter-comparison) \\
10 May 2008 $(\mathrm{am})$ & B368 & - & Sweden/Finland/Baltic Sea \\
10 May 2008 $(\mathrm{pm})$ & B369 & - & Baltic Sea/Germany \\
12 May 2008 $(\mathrm{am})$ & B370 & - & Germany/Netherlands/North Sea \\
12 May 2008 $(\mathrm{pm})$ & B371 & - & Germany/Baltic Sea \\
13 May 2008 $(\mathrm{pm})$ & B373 & $080513 \mathrm{~b}$ & English Coast circuit/Western Ireland \\
14 May 2008 $(\mathrm{am})$ & B374 & $080514 \mathrm{a}$ & Irish Sea, Atlantic Ocean southwest of Ireland \\
14 May 2008 $(\mathrm{pm})$ & - & $080514 \mathrm{~b}$ & transit from Ireland to Germany \\
20 May 2008 & - & $080520 \mathrm{a}$ & Eastern Germany/Poland/Baltic Sea \\
21 May 2008 $(\mathrm{am})$ & B379 & $050821 \mathrm{a}$ & Northern Germany/Netherlands/Belgium \\
21 May 2008 $(\mathrm{pm})$ & - & $080521 \mathrm{~b}$ & Northern Germany/Netherland/Belgium \\
22 May 2008 $(\mathrm{am})$ & B380 & $080522 \mathrm{a}$ & Germany/Netherlands/Belgium/English Channel/England \\
22 May 2008 $(\mathrm{pm})$ & - & $080522 \mathrm{~b}$ & Germany/Netherlands/Belgium/English Channel/England \\
18 September 2008 & B401 & - & English Channel/Southwest England \\
19 September 2008 & B402 & - & England east coast \\
23 September 2008 & B404 & - & England southwest coast \\
25 September 2008 & B406 & - & Circuit around England \\
\hline
\end{tabular}

in more detail than for the LONGREX campaign. ADIENT flights targeted conditions with clear skies and little influence from precipitation. Meteorological data were obtained from the ECMWF (European Centre for Medium-Range Weather Forecasts) interim re-analysis, a development of the ERA-40 re-analysis.

A high pressure system located west of the Bay of Biscay resulted in relatively strong northwesterly flow over most of the UK during the 2 April 2008 flight (B355). Measurements were concentrated along the east coast of the UK examining plumes from cities along the east coast including Edinburgh, Newcastle and Hull. The 10 April 2008 flight also measured pollution along the east coast, but the mean flow during this period was southwesterly due to a low-pressure system northwest of Ireland, so the aircraft sampled pollution from a broad swath of southern England. The 16 April 2008 flight took place in easterly-flow conditions. A broad region of high pressure to the north and northeast of the UK during the flight resulted in a relatively weak southeasterly flow. The flight measured pollution emitted over a broad region of the UK, especially the Liverpool/Manchester region in northwestern England, as the pollution advected to the northwest.
A weak ridge of high pressure, drifting to the north, resulted in weak easterly flow over southern England during the first two flights of the September period (18 and 19 September; B401 and B402). A low-pressure system north of the UK led to westerly flow over most of northern England and Scotland. The 18 September flight examined pollution in the easterly flow in the English channel, while the 19 September flight examined pollution in the westerly flow along the east coast of England and Scotland. The remaining three September flights took place from 23-25 September. During this period a high pressure system drifted from west of Scotland to the west of Denmark. The resulting flow of the UK was easterly for all three flights. The 23 September flight examined pollution downwind of the UK in the Bristol Channel. The 24 September flight examined flow coming into the UK from northern Europe, flying along the eastern UK coast. The 25 September flight examined pollution coming into the UK on the east and pollution exiting the UK to the west, flying a circuit around the whole of southern England.

Conditions during the ADIENT and LONGREX flights examined here fall into four categories with respect to the UK. During westerlies, the focus of the flights was to 


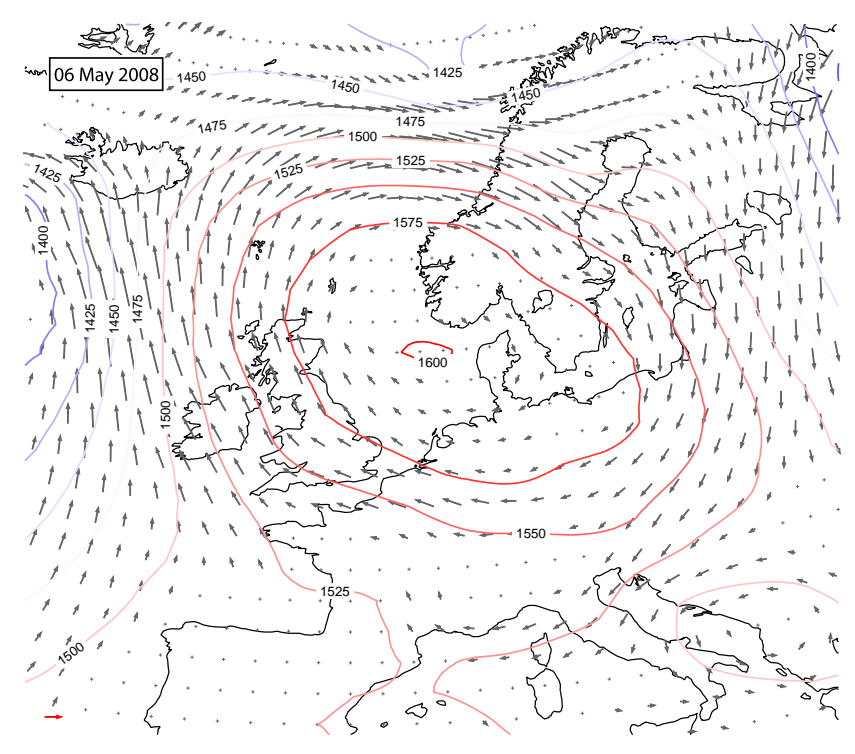

Fig. 2. Map showing the ECMWF re-analysis $850 \mathrm{hPa}$ geopotential height (m) at 12:00 UTC for the 6 May 2008 flights (B362 and B363). Contour interval is $25 \mathrm{~m}$. Arrows indicate $850 \mathrm{hPa}$ wind speed and direction; red arrow in lower left corner illustrates a westerly $10 \mathrm{~m} \mathrm{~s}^{-1}$ wind.

characterize pollution upwind and downwind of the UK. Aerosol loadings were expected to be relatively low for flights upwind of the UK during westerly-dominated conditions (Atlantic inflow) and higher for flights downwind of the UK (Morgan et al., 2009). During easterlies, flights upwind of the UK captured pollution transported from Europe and flights downwind of the UK measured a combination of pollution from the UK and Europe. Higher aerosol loadings were expected compared to flights taking place in westerlies (Morgan et al., 2009). The majority of flights over continental Europe during LONGREX took place during conditions dominated by high pressure over Denmark and the surrounding region, so flow was easterly, with the exception of flights over Scandinavia, when flow was anti-cyclonic with a stronger northerly component.

Morgan et al. (2010a) describe the total sub-micron aerosol mass concentrations measured by the AMS for most of the flights discussed here. They found highest sub-micron aerosol mass concentrations over northwestern Europe and off the coast of southern England during the May 2008 LONGREX measurement period. A similar spatial pattern was observed for aerosol sub-micron volume concentrations derived from PCASP size distribution measurements and total aerosol scattering coefficients measured by the nephelometer. The maximum SLR-averaged sub-micron aerosol mass concentrations in the region were on the order of $20 \mu \mathrm{g} \mathrm{s} \mathrm{m}^{-3}$. Concentrations tended to be lower to the north and east, dropping to a few $\mu \mathrm{g} \mathrm{s} \mathrm{m}^{-3}$ over the Baltic Sea. Organic matter $(\mathrm{OM})$ and ammonium nitrate were the dominant chemical species contributing to aerosol mass as measured by the
AMS, each contributing between $20-50 \%$ of the total mass. Ammonium sulphate had larger contributions in the north and east. The results were consistent with the meteorological conditions during the observation period (anti-cyclonic flow with easterlies over most of northern Europe) and the distribution of $\mathrm{NO}_{\mathrm{x}}, \mathrm{SO}_{2}$ and $\mathrm{NH}_{3}$ emission sources in $\mathrm{Eu}-$ rope (Morgan et al., 2010a).

\section{2 rBC mass concentrations}

Figure 3a shows SLR-averaged rBC mass concentrations for all flights, with points coloured by the date of the measurement. The April and September ADIENT flights were concentrated around the UK, whereas the May LONGREX flights focused on continental Europe, but also included regions of the UK and together cover a larger area than that probed during ADIENT. Most of the SLRs were confined between 200-2000 $\mathrm{m}$ and the average SLR altitude was 900 $\mathrm{m}$. Black carbon mass concentrations were highest over the Belgium/Netherlands region, the English Channel, and in urban plumes sampled downwind of the western and eastern UK coasts, where the highest run-averaged $\mathrm{rBC}$ mass concentrations were on the order of $300 \mathrm{ng} \mathrm{s} \mathrm{m}^{-3}$. The lowest $\mathrm{rBC}$ concentrations (on the order of $20-60 \mathrm{ng} \mathrm{s} \mathrm{m}^{-3}$ ) were observed over the Baltic Sea region and off the northeastern English coast during periods dominated by northeasterly winds.

The spatial distribution of $\mathrm{rBC}$ depicted in Fig. 3a reflects $\mathrm{rBC}$ source regions and the meteorological conditions at the time of the measurements. Wind speed and direction averaged over the same period as the $\mathrm{rBC}$ mass concentrations are shown in Fig. 3b. The majority of the continental European $\mathrm{rBC}$ measurements were associated with weak easterly flow, consistent with the location of the high pressure system at this time. The rBC mass concentrations tended to increase from east to west during LONGREX. Conditions for UK measurements were more variable. Black carbon mass concentrations observed off the eastern UK coast were low for periods when winds were more northerly (transport from the North Sea and cleaner Arctic air masses) and higher when they had easterly or westerly components (polluted UK or continental European air masses).

The rBC mass concentrations measured over all of Europe during the LONGREX high-pressure dominated periods are summarized in Fig. 4a. Mean rBC concentrations increased from $\sim 50 \mathrm{ng} \mathrm{s} \mathrm{m}^{-3}$ at the eastern extent of the operational area to $\sim 180 \mathrm{ng} \mathrm{s} \mathrm{m}^{-3}$ in the region bounded by 5 and $10^{\circ} \mathrm{W}$ longitude). The variability in $\mathrm{rBC}$ mass concentrations was largest between $0-20^{\circ} \mathrm{E}$ and skewed to higher concentrations, reflecting the higher density of $\mathrm{rBC}$ sources over continental Europe encountered during these flights. The minimum rBC mass concentration in each longitude bin also tended to increase from east to west, reflecting the accumulation of pollution in the air masses as they moved west. Examination of satellite data showed little cloud cover over the 


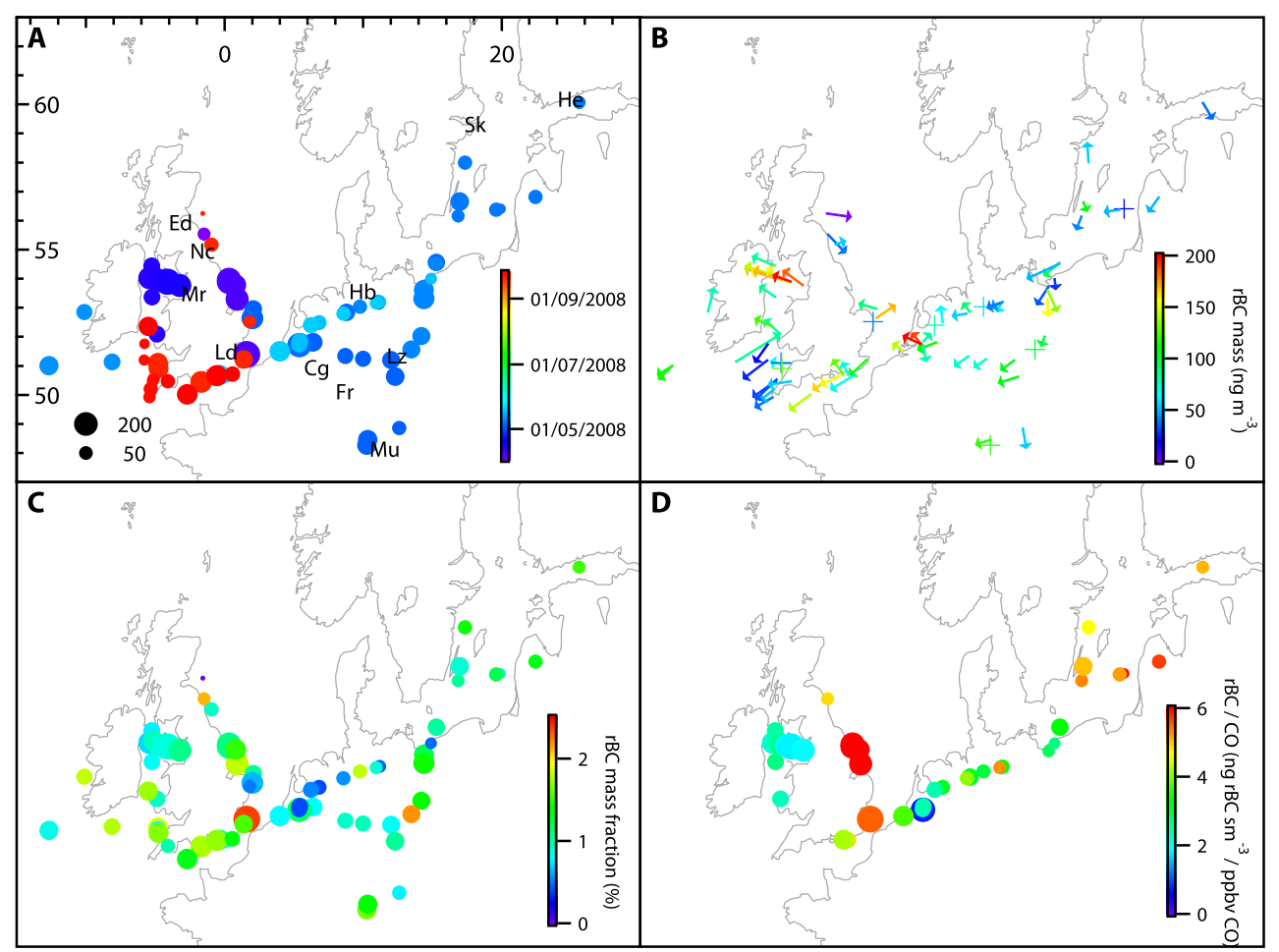

Fig. 3. Maps showing spatial distribution of refractory black carbon (rBC) averaged over straight and level runs (SLRs) below $3000 \mathrm{~m}$. Points are sized by rBC mass concentrations and coloured by: (a) date/campaign; (b) rBC mass; (c) rBC mass fraction of fine aerosol mass (PCASP); and (d) rBC/excess carbon monoxide ratios. Points in panel b are shaded by $\mathrm{rBC}$ mass concentration and indicate the average wind speed and direction for each SLR. The longest wind speed arrow represents $15 \mathrm{~m} \mathrm{~s}^{-1}$. Locations of selected cities are shown in panel a $(\mathrm{Mr}=$ Manchester, $\mathrm{Ld}=$ London, $\mathrm{Nc}=$ Newcastle, $\mathrm{Br}=$ Brussels, $\mathrm{Fr}=$ Frankfurt, $\mathrm{Mu}=$ Munich, $\mathrm{Hb}=\mathrm{Hamburg}, \mathrm{Sk}=\mathrm{Stockholm}$, and $\mathrm{He}=$ Helsinki).

measurement region during the high-pressure dominated periods, so there was likely little removal of $\mathrm{rBC}$ through scavenging by clouds or precipitation, which is consistent with the observed $\mathrm{rBC}$ mass concentration gradients.

Information on the vertical structure of $\mathrm{rBC}$ mass loadings was mainly limited to the April and September ADIENT flights due to the altitude-dependent SP2 problem during LONGREX. Figure 5 summarises the statistics of the rBC mass concentrations for the measurement campaign separated into altitude bins. rBC mass concentrations were highest in the boundary layer near the surface with a mean value and standard deviation of $120 \pm 80 \mathrm{ng} \mathrm{s} \mathrm{m}^{-3}$. The average rBC mass concentrations decreased with increasing altitude for the lowest $\sim 2000 \mathrm{~m}$ of the boundary layer to roughly $50 \mathrm{ng} \mathrm{s} \mathrm{m}^{-3}$, then decreased further by a factor of 10 over the next few hundred meters reaching an average concentration of about $5 \mathrm{ng} \mathrm{s} \mathrm{m}^{-3}$ in the middle free troposphere. The variability in $\mathrm{rBC}$ mass concentrations for any given layer depended on the horizontal heterogeneity of rBC mass concentrations measured, variability in the boundary layer height, and the number of samples collected in a given altitude range. Free troposphere $(>3 \mathrm{~km}) \mathrm{rBC}$ mass concentrations did not exceed $100 \mathrm{ng} \mathrm{s} \mathrm{m}^{-3}$.

\subsection{Light absorption measurements}

The FAAM and DLR Falcon aircraft carried PSAP instruments to measure aerosol light absorption. The relationship between absorption and the mass of the absorbing species depends on the size, composition, structure and mixing state of the material (Bond and Bergstrom, 2006). The measurement of aerosol light absorption coefficients $\left(b_{a p}\right)$ using filter-based techniques such as that employed by the PSAP is also prone to a number of artefacts as discussed previously. For these reasons we do not expect $b_{a p}$ and $\mathrm{rBC}$ mass concentrations measured by the SP2 to be perfectly correlated, but we do expect a positive relationship between the two. The PSAP data are also available over a broader geographic range and altitude range than the SP2 measurements, so we include them in our analysis of the $\mathrm{rBC}$ distribution over $\mathrm{Eu}-$ rope.

Figure 6 compares PSAP-measured $b_{a p}$ to SP2-measured $\mathrm{rBC}$ mass concentrations for three FAAM flights during the campaign and the below $3 \mathrm{~km}$ SLR averaged values for the entire period. The absorption and $\mathrm{rBC}$ mass measurements were positively correlated for individual flights and for the SLR-averaged values (Pearsons $r$-squared $=0.57$ ). The 


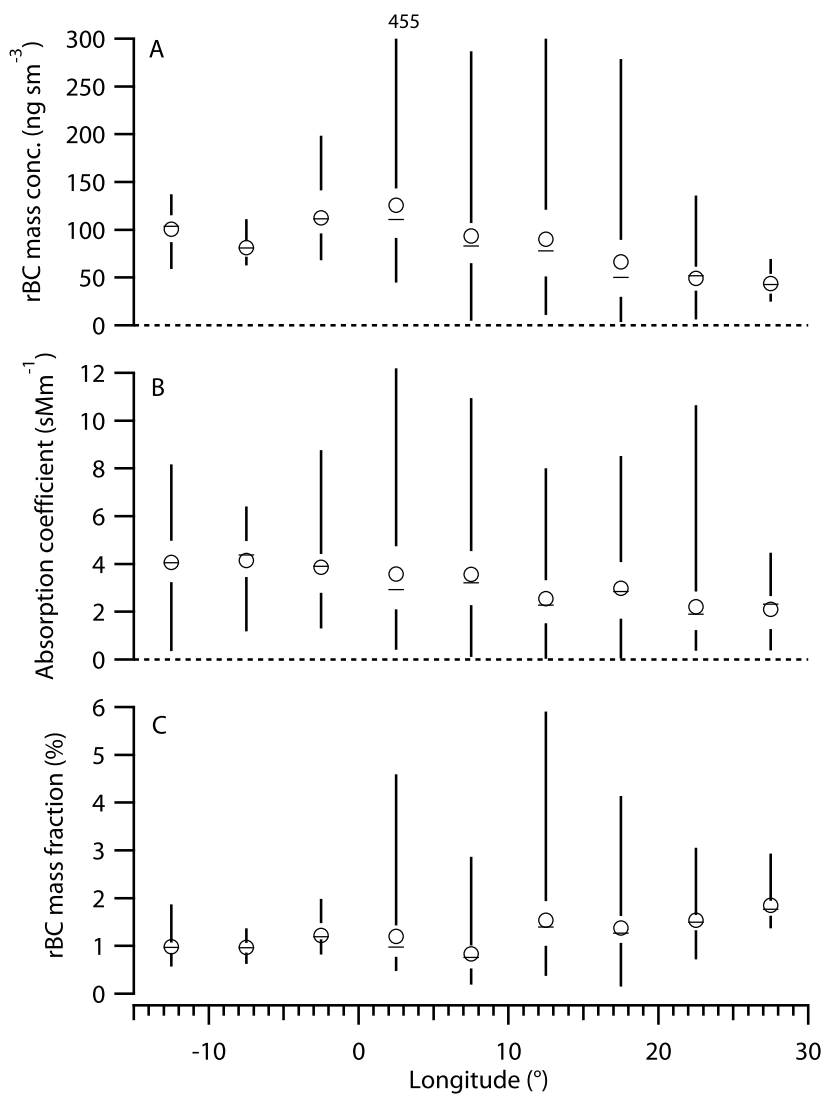

Fig. 4. Whisker plots showing the statistics for (a) SP2-measured refractory black carbon (rBC) mass concentrations, (b) PSAPmeasured absorption coefficients and (c) rBC mass fractions (calculated from $\mathrm{rBC}$ mass concentrations and PCASP-estimated mass concentrations) for $5^{\circ}$ longitude bins during the EUCAARILONGREX component of the campaign. Whiskers indicate the minimum value to 25 th percentile and 75 th percentile to maximum value. Medians are indicated by horizontal lines, means by circles and the number of individual measurements for each bin are indicated to the right of the data points. Note the number of measurements in each bin are not identical because of differences in data coverage for the SP2, PSAP and PCASP.

regression coefficients for each fit represent the mass absorption efficiency $(\alpha)$, however these values likely overestimate the true $\alpha$ because the size range of the PSAP is larger than that of the SP2 and the PSAP measurement was likely affected by a number of artefacts discussed previously. We observed approximately twice as high $\alpha$ values during the September flights compared to the April and May observation periods, but we did not observe a clear geographic pattern in $\alpha$ values. The correlation between $b_{a p}$ and $\mathrm{rBC}$ mass concentrations was strongest for the 16 April (B357) flight which sampled relatively fresh emissions from the Manchester/Liverpool conurbation.

The FAAM aircraft PSAP measurements shown in Fig. 7a indicate a similar pattern in $b_{a p}$ over Europe compared to the
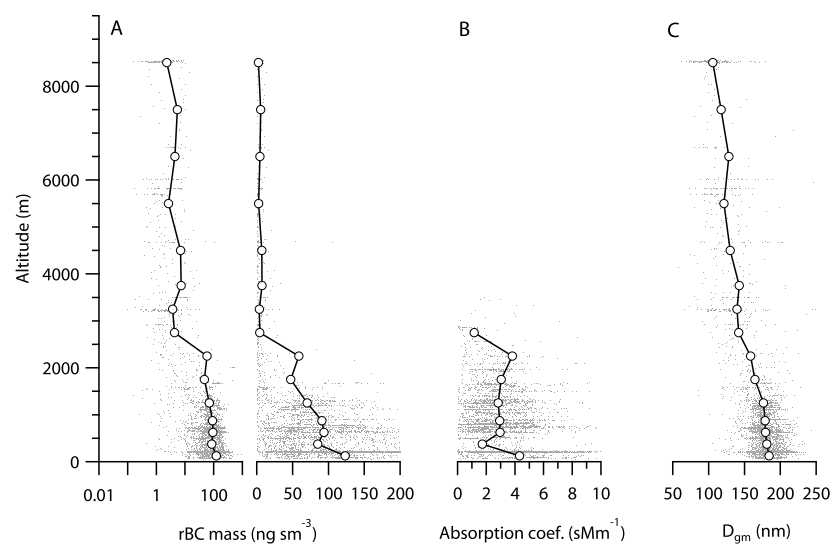

Fig. 5. Profiles of (a) refractory black carbon (rBC) mass concentrations on log and linear scales, (b) absorption coefficient and (c) rBC mass mean diameter for all flights. Individual 30-s averaged points are shown in gray; mean values for 250 to $1000 \mathrm{~m}$ thick altitude bins are shown by black circles.

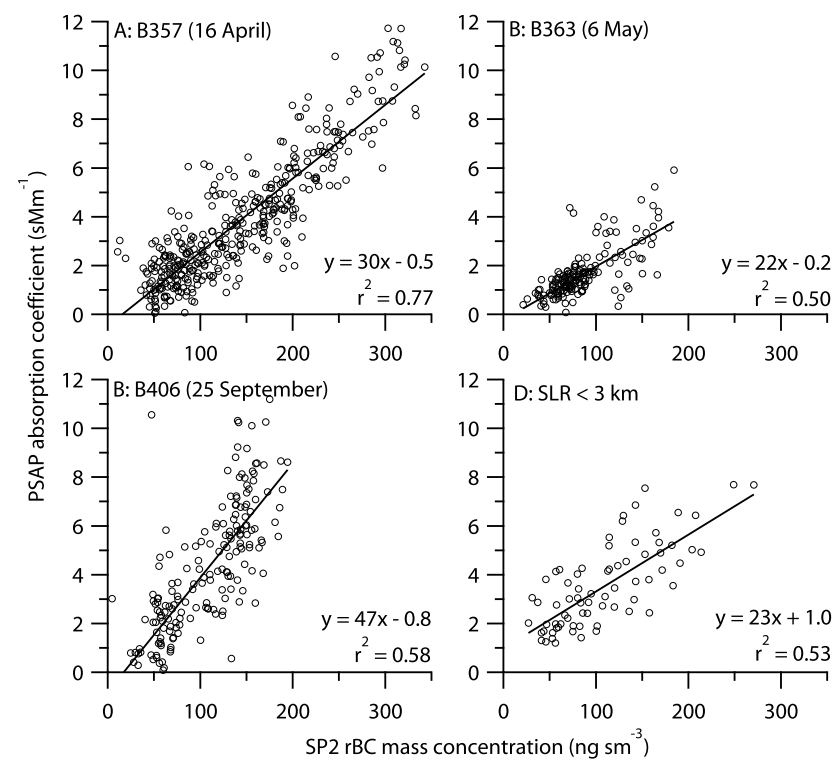

Fig. 6. Scatter plots comparing FAAM research aircraft PSAPmeasured aerosol light absorption coefficients to SP2-measured refractory black carbon mass concentrations for three individual flights during the (a) April, (b) May and (c) September portions of the campaign and (d) for all straight and level averages below $3 \mathrm{~km}$ altitude. The linear least-square regression of the PSAP data to the SP2 refractory black carbon concentration measurements and square of the Pearson correlation coefficient $\left(r^{2}\right)$ are also shown for each case.

SP2 rBC mass measurements. Higher values were observed near urban areas in the Netherlands and northwestern Germany and around the UK. Absorption coefficient values were also higher in the European outflow measured to the southwest of Ireland relative to observations in the eastern half of 

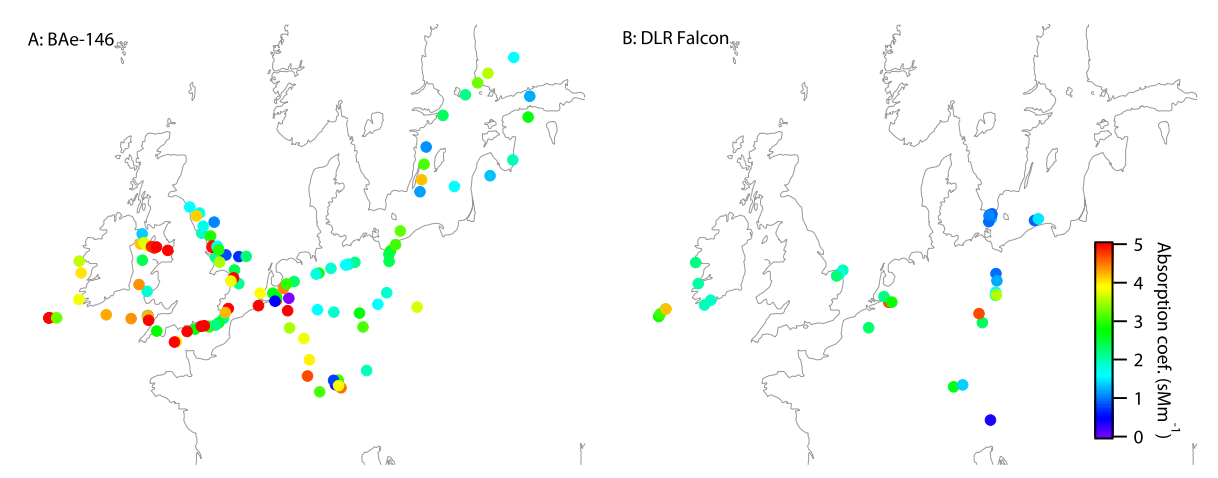

Fig. 7. Maps showing average aerosol light absorption coefficients measured by particle soot absorption photometers on the (a) FAAM and (b) DLR research aircraft. Observations are restricted to periods when the aircraft were below $3 \mathrm{~km}$ altitude.

the measurement region. Figure $7 \mathrm{~b}$ shows $b_{a p}$ measured by the PSAP on board the DLR Falcon for periods when the aircraft was below $3 \mathrm{~km}$ in altitude. The average altitudes examined by both aircraft were similar, except the FAAM aircraft measurements around the UK were typically lower in altitude than the European FAAM and DLR aircraft measurements. The DLR observations displayed a similar spatial pattern to the FAAM results, with higher absorption coefficients measured near urban areas near Leipzig, Germany and Cabauw in the Netherlands. The Falcon PSAP measurements also found relatively high $b_{a p}$ off the southwest coast of Ireland.

We also observed an east-west gradient in $b_{a p}$ during the high-pressure dominated periods of LONGREX, shown in Fig. 4. Profiles are not included in the longitude averages because of uncertainties in the flow rate of the PSAP for changing pressures. The average $b_{a p}$ doubled from approximately $2 \mathrm{sMm}^{-1}\left(1 \mathrm{sMm}^{-1}\right.$ is $1 \mathrm{Mm}^{-1}$ at STP $)$ at the eastern end of the measurement range to approximately $4 \mathrm{sMm}^{-1}$ at the western extreme. The general structure in the $\mathrm{rBC}$ and $b_{a p} \mathrm{E}-$ $\mathrm{W}$ gradients was similar. The largest variability in both measurements was observed in The Netherlands region $\left(0-5^{\circ} \mathrm{E}\right)$ where a number of individual plumes were encountered.

The FAAM aircraft and DLR Falcon participated in an inter-comparison exercise on the 9 May 2008 to compare a number of similar measurements on board each aircraft, including PSAP absorption coefficient measurements. The flights took place near the LONGREX base of operation, Oberpfaffenhofen, Germany. The FAAM aircraft uncorrected PSAP $b_{a p}$ averaged over the low-level $(1200 \mathrm{~m}$ altitude) inter-comparison leg was $5.9 \pm 1.5 \mathrm{Mm}^{-1}$ compared to the DLR Falcon uncorrected PSAP $b_{a p}$ of $4.2 \pm 0.5 \mathrm{Mm}^{-1}$. The corrected $b_{a p}$ values measured by each aircraft were $3.1 \pm 0.7 \mathrm{Mm}^{-1}$ and $2.7 \pm 0.4 \mathrm{Mm}^{-1}$ for the FAAM aircraft and DLR Falcon, respectively.

\section{4 rBC mass fractions}

To examine the relationship between $\mathrm{rBC}$ mass and total aerosol mass, we compared rBC mass concentrations averaged over the sub- $3 \mathrm{~km}$ altitude SLRs to additional measurements of sub-micron aerosol mass averaged over the same flight legs. Figure 3c shows $\mathrm{rBC}$ mass concentrations shaded by $\mathrm{rBC}$ mass fraction, where $\mathrm{rBC}$ mass fraction was calculated by dividing measured $\mathrm{rBC}$ mass by the PCASP-estimated sub-micron mass concentrations. The PCASP sub-micron mass concentrations were obtained by multiplying PCASP volume concentrations by density estimated from AMS composition measurements (Morgan et al., 2010a). Black carbon mass was correlated with sub-micron mass (Pearsons $r^{2}=0.50$ ) and made up between $0.5-3.5 \%$ of sub-micron aerosol mass. The boundary layer SLRaveraged rBC mass fractions did not display a strong geographic dependence during the LONGREX period, either (Fig. 4c). Slightly lower rBC mass fractions were observed over the Belgium/Netherlands region $\left(0-10^{\circ} \mathrm{E}\right)$, showing that the increased $\mathrm{rBC}$ mass concentrations in the region were more than balanced by increases in other secondary aerosol species, primarily ammonium nitrate (Morgan et al., 2010a).

We also compared $\mathrm{rBC}$ mass to AMS measurements of sub-micron mass, which on average were approximately $40 \%$ higher than those estimated from the PCASP-derived mass values. We added the $\mathrm{rBC}$ mass concentrations measured by the SP2 to the AMS mass measurement because the AMS is not sensitive to refractory material such as $\mathrm{rBC}$. The geographic pattern in $\mathrm{rBC}$ mass fractions calculated from AMS data was similar that observed for the PCASP-based rBC mass fractions. The only exceptions were observed during flight B357 (downwind of the Liverpool/Manchester conurbation), for which the AMS-measured mass was approximately half of that estimated by the PCASP (Morgan et al., 2010a), which translated to rBC mass fractions on the order of $3.5 \%$, roughly double the PCASP-based estimate. 

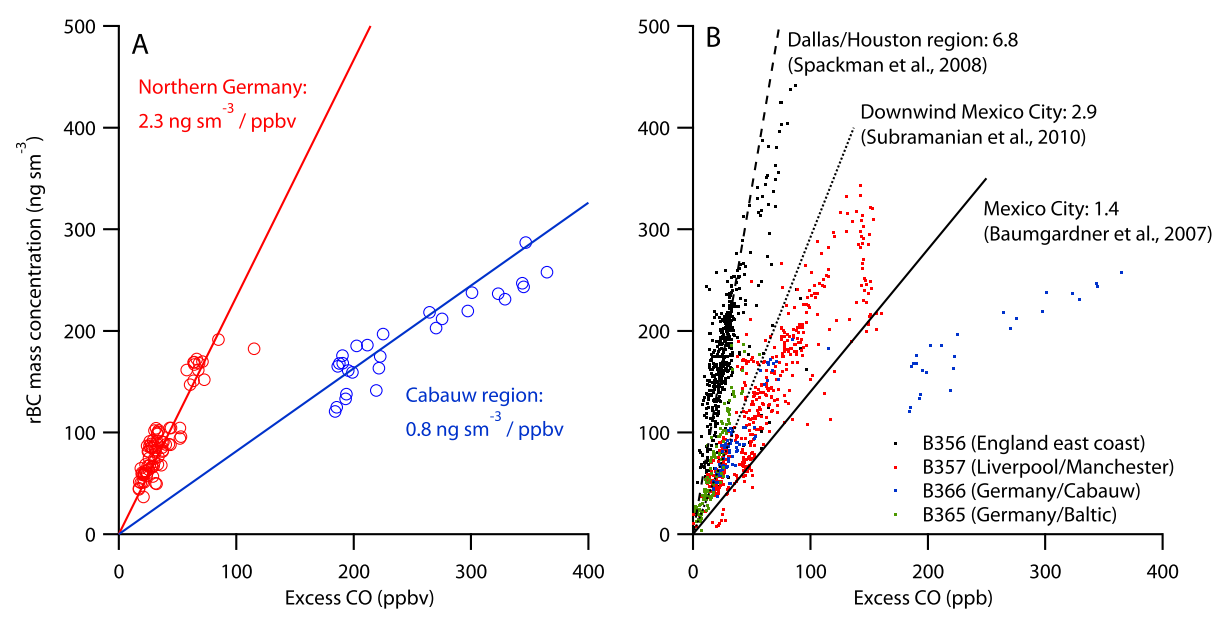

Fig. 8. Refractory black carbon mass concentrations $\left(\mathrm{ng} \mathrm{s} \mathrm{m}^{-3}\right)$ plotted against excess carbon monoxide mixing ratios (ppbv) for (a) 8 May 2008 (B366) and (b) B366 and three additional flights. Each data point represents a 20-30s average, depending on the AMS time resolution. Solid coloured lines in (a) give the linear regression (forced through the origin) of rBC onto excess CO. The dashed line in (b) shows the regression coefficient provided by Spackman et al. (2008) for aircraft-based measurements in urban and industrial outflow near Dallas and Houston, Texas, USA, adjusted to the same units as our data and for the 1.1 scaling factor applied to the Spackman et al. (2008) data. The solid and dotted lines show the regressions reported by Baumgardner et al. (2007) and Subramanian et al. (2010) for ground- and aircraft-based SP2 observations in and downwind of Mexico City.

\subsection{Relationship between black carbon and carbon monoxide}

Black carbon and carbon monoxide $(\mathrm{CO})$ are both products of incomplete combustion and have similar sources, such as traffic exhaust and biomass burning. Their emission ratios constrain global and regional models, providing a useful test for their performance. The emission ratio of $\mathrm{rBC}$ to $\mathrm{CO}$ varies significantly with source (Bond et al., 2004), so variations in measured ratios can indicate the presence of different sources. Other factors influence $\mathrm{rBC}-\mathrm{CO}$ ratios. $\mathrm{rBC}$ is removed by wet deposition, but $\mathrm{CO}$ is not. Unlike $\mathrm{rBC}, \mathrm{CO}$ has a significant source from VOC oxidation. The atmospheric lifetime of $\mathrm{rBC}$ is shorter than $\mathrm{CO}$ (approximately 10 days versus 1 month in summer), so variations in $\mathrm{rBC}-\mathrm{CO}$ ratios also reflect sample age and wet removal processes in addition to sources. We expect the loss of $\mathrm{rBC}$ in precipitation scavenging in the boundary layer to be minor for most of the flights considered here due to the absence of precipitation in the study region.

To examine European-scale emissions, we first estimated and removed "background" $\mathrm{CO}$ mixing ratios from the intercept of the linear regression of $\mathrm{CO}$ mixing ratio on $\mathrm{rBC}$ mass concentrations for each flight, reported in Table 2. We refer to CO mixing ratios above this background as "excess" $\mathrm{CO}(\triangle \mathrm{CO})$. The analysis was not performed for flights with poor $\mathrm{rBC}$ or $\mathrm{CO}$ data coverage or when there was only a "weak" correlation $\left(r^{2}<0.5\right)$ between $\mathrm{rBC}$ and $\mathrm{CO}$, making it difficult to determine the background $\mathrm{CO}$ value. Morgan et al. (2010a) identified two distinct periods during the LONGREX campaign based on gas-phase measurements, including $\mathrm{CO}$, and changes in meteorology: LONGREX-1 (6-8 May) and LONGREX-2 (10-14 May). Flow during LONGREX-1 was more zonal compared to LONGREX-2, by which point the high pressure system established more anti-cyclonic flow over the region, with a stronger northerly component (Morgan et al., 2010a). Background CO mixing ratios during LONGREX-1 were on the order of $200 \mathrm{ppbv}$ compared to approximately $120 \mathrm{ppbv}$ during LONGREX-2 and after. Carbon monoxide concentrations were between 150-180 ppbv during the April ADIENT flights. The CO instrument was not available for the September ADIENT flights.

The relationship between $\mathrm{rBC}$ and $\triangle \mathrm{CO}$ was determined by performing a linear regression of $\mathrm{rBC}$ mass concentrations onto the $\triangle \mathrm{CO}$ mixing ratios. Two regressions were performed in cases where a clear non-linearity in the relationship between $\mathrm{rBC}$ and $\triangle \mathrm{CO}$ was observed which were associated with distinct periods in time and space. For example, during the 8 May 2008 afternoon flight (B366), we observed two distinct relationships between $\mathrm{rBC}$ and $\triangle \mathrm{CO}$ over northern Germany and in plumes in the Cabauw region of the Netherlands (Fig. 8a).

Data from selected individual flights are summarized in Fig. $8 \mathrm{~b}$ to give an indication of the variability during single flights and between flights. The $\mathrm{rBC} / \Delta \mathrm{CO}$ ratios for flights where background $\mathrm{CO}$ values could be determined were between 0.8 and $6.2 \mathrm{ng} \mathrm{rBC} \mathrm{s} \mathrm{m}^{-3} \mathrm{ppbv}^{-1} \mathrm{CO}$. The lowest value was observed in plumes in the vicinity of Cabauw, Netherlands on 8 May 2008 and the highest value was observed in the English Channel on 10 April 2008. Figure $3 \mathrm{~d}$ shows the spatial pattern in SLR-averaged $\mathrm{rBC} / \triangle \mathrm{CO}$ 
Table 2. List of flight-averaged "background" carbon monoxide $\left(\mathrm{CO}_{b g}\right)$ mixing ratios, $\mathrm{rBC} / \Delta \mathrm{CO}$ ratios, and coefficient of determination for the relationship between $\mathrm{rBC}$ mass concentrations and $\triangle \mathrm{CO}$ mixing ratios. Statistical uncertainties from the regressions used to obtain the $\mathrm{CO}_{b g}$ values and $\mathrm{rBC} / \Delta \mathrm{CO}$ ratios are also listed.

\begin{tabular}{llccc}
\hline Date & Flight No. & $\mathrm{CO}_{b g}(\mathrm{ppbv})$ & $\mathrm{rBC} / \Delta \mathrm{CO}\left(\mathrm{ng} \mathrm{s} \mathrm{m}^{-3} / \mathrm{ppbv}\right)$ & $r^{2}$ \\
\hline 2 April 2008 & B355 & $187 \pm 1$ & $4.4 \pm 0.2$ & 0.55 \\
10 April 2008 & $\mathrm{B} 356^{1}$ & $153 \pm 2$ & $6.2 \pm 0.1$ & 0.76 \\
16 April 2008 & B357 & $153 \pm 2$ & $2.1 \pm 0.1$ & 0.80 \\
8 May 2008 (am) & B365 & $209 \pm 1$ & $3.3 \pm 0.1$ & 0.86 \\
8 May 2008 (pm) & $\mathrm{B} 366^{2}$ & $196 \pm 2$ & $2.3 \pm 0.1$ & 0.83 \\
8 May 2008 (pm) & ${\mathrm{B} 366^{3}}_{1}$ & $71 \pm 21$ & $0.8 \pm 0.1$ & 0.85 \\
10 May 2008 (am) & B368 & $126 \pm 2$ & $4.9 \pm 0.2$ & 0.74 \\
10 May 2008 (pm) & B369 & $120 \pm 1$ & $4.9 \pm 0.1$ & 0.71 \\
12 May 2008 (am) & B370 & $113 \pm 2$ & $2.7 \pm 0.1$ & 0.60 \\
21 May 2008 & B379 & $137 \pm 1$ & $2.8 \pm 0.1$ & 0.71 \\
22 May 2008 & B380 & $131 \pm 1$ & $3.5 \pm 0.1$ & 0.82 \\
\hline
\end{tabular}

1 Non-plume

2 Northern Germany only

3 Cabauw, Netherlands only

ratios for flights where the background $\mathrm{CO}$ could be determined with confidence. They were lowest in the Manchester/Liverpool plume and near Cabauw in the Netherlands. The highest ratios were observed off of the UK eastern coast in April, with intermediate values over northern Germany and off the south coast of the UK.

\subsection{Black carbon size distributions}

Examples of four normalized rBC "core" mass distributions averaged over segments of individual flights are shown in Fig. 9a-d. Note that the rBC "core" mass distributions do not include the contribution by non-rBC material to the particle diameter. $\mathrm{rBC}$ particles internally mixed with appreciable amounts of non-rBC material will be larger than our reported diameters. Distributions a-c are averages of mass distributions measured in the Liverpool/Manchester plume, over the Atlantic Ocean, and in the vicinity of Cabauw, Netherlands, respectively, while distribution $\mathrm{d}$ was observed on the ground at Cranfield, UK (the aircraft's base of operations during the ADIENT missions) at the end of the 23 September (B404) flight. The Liverpool/Manchester and Cabauw distributions represent relatively fresh outflow from urban areas while the Atlantic Ocean observations represent relatively processed continental outflow. These classifications are based on an analysis of the meteorology and AMS organic aerosol characteristics during the campaign (Hamburger et al., 2010; Morgan et al., 2010a). The Cranfield ground-based distribution represents fresh emissions, most likely from jet engine exhaust or the ground power unit (GPU) used to provide power to the aircraft on the ground.

We fit log-normal distributions to the data (e.g., Schwarz et al., 2006) to determine the mass median diameter (MMD) and geometric standard deviation $\left(\sigma_{g}\right)$ for each distribution, listed in Table 4. All four distributions are described well by a single log-normal fit, consistent with previous observations (Schwarz et al., 2006; Shiraiwa et al., 2007; Schwarz et al., 2008b; Subramanian et al., 2010, e.g.,). The Cranfield distribution had the smallest MMD, followed by the two fresh urban outflow distributions and the processed Irish Sea observations. The differences between ambient and Cranfield distributions were much larger than the differences among ambient distributions observed during the campaign.

We also calculated the mass geometric mean diameter $\left(D_{g m}\right)$ for each AMS-averaged rBC mass distribution using:

$\log D_{g m}=\frac{\sum_{D_{\min }}^{D_{\max }} \log D_{g, i} d M_{i}}{M}$

where $D_{\max }$ and $D_{\min }$ are the upper and lower diameter limits of the valid measurement range, $D_{g, i}$ is the geometric midpoint of each bin in the size distribution, $d M_{i}$ is the mass in each bin, and $M$ is the total $\mathrm{rBC}$ mass. Note that $D_{g m}$ is not equivalent to the MMD obtained from the log-normal fit because of the different weighting given to the bins. For example, $D_{g m}$ measured over the Atlantic Ocean was $199 \mathrm{~nm}$ compared to the fit mean size of $210 \mathrm{~nm}$ for the size distribution illustrated in Fig. 9.

Figure 9 shows the SLR-averaged $D_{g m}$ values for $\mathrm{rBC}$ in the boundary layer (below $3 \mathrm{~km}$ ). Run-averaged $D_{g m}$ fell between $160-210 \mathrm{~nm}$, with smaller values near and downwind of urban source regions and larger values in more remote areas. The spatial pattern was relatively weak, however, and there were exceptions to the general pattern. The mean diameters of rBC observed in the English channel and plumes encountered over the eastern coast of the UK were larger than 


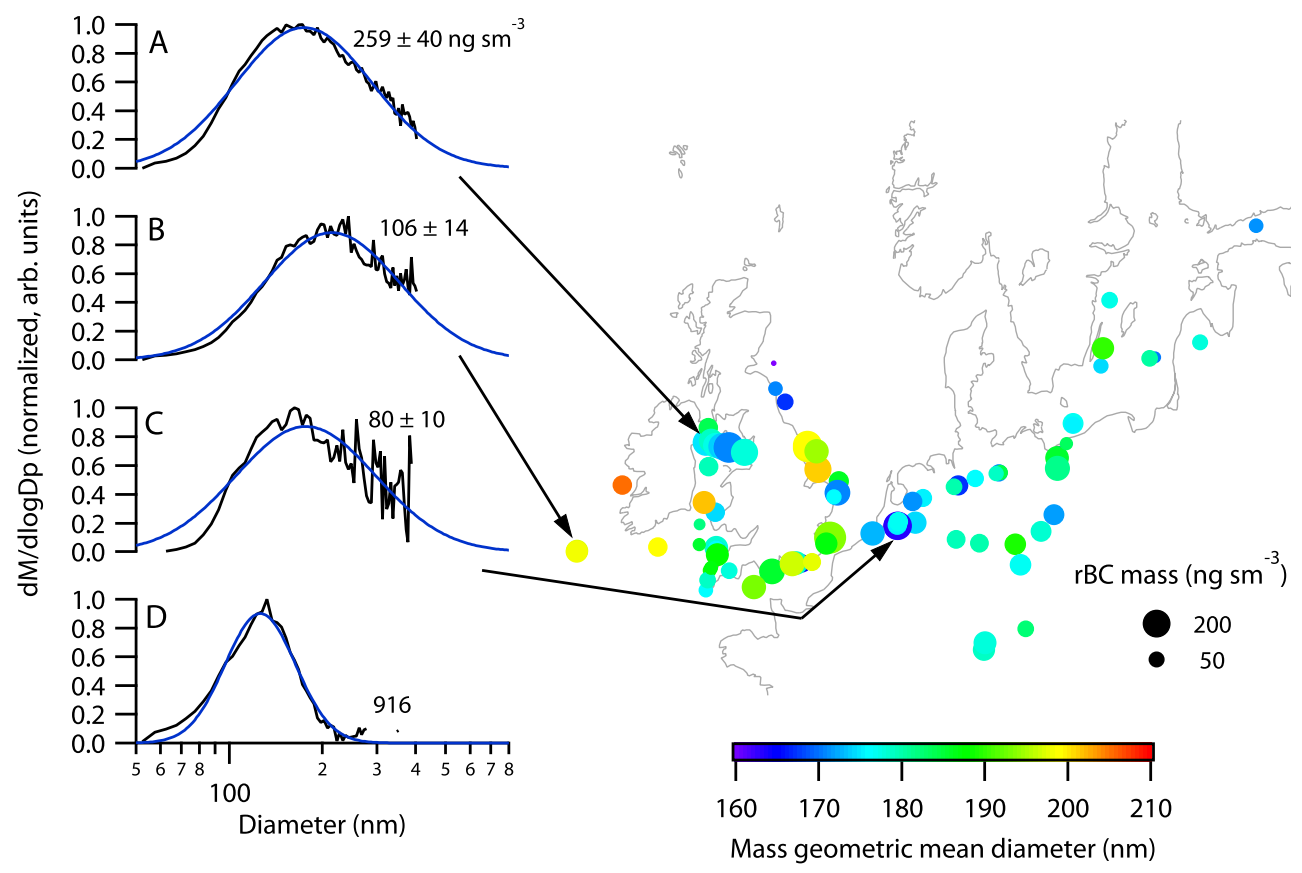

Fig. 9. Map showing refractory black carbon (rBC) mass concentrations and geometric mean diameters averaged over straight and level runs (SLRs) below $3 \mathrm{~km}$. Points are scaled by rBC mass concentration and shaded by geometric mean diameter. Mass distributions (dM/dlogDp), normalized by their peak value and averaged in three different regions (a-c, indicated by black arrows) are also shown. A fourth mass size distribution (d) shows the rBC distribution measured on the ground at the aircraft base in close proximity to ground power units and other aircraft. rBC mass concentrations for each mass distribution are also shown.

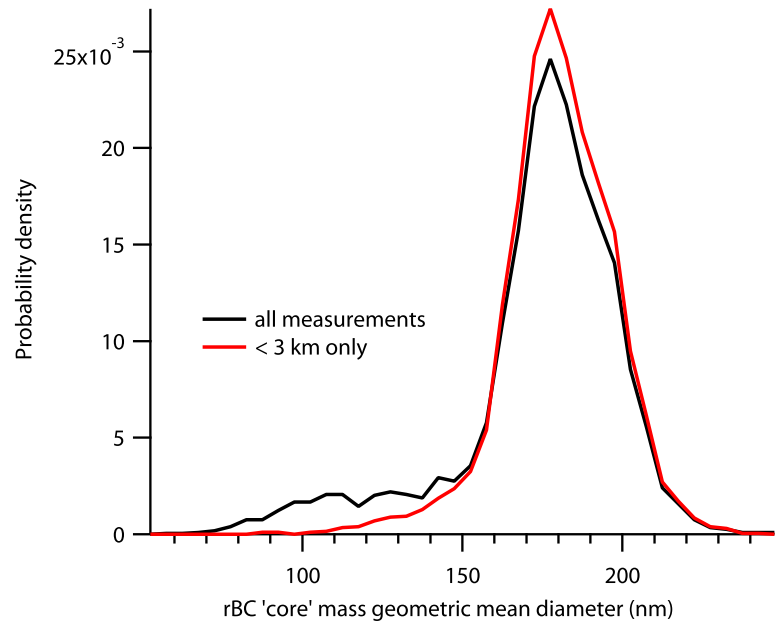

Fig. 10. SP2-measured refractory black carbon $(\mathrm{rBC})$ "core" mass geometric mean diameters shown as a probability distribution function (PDF) for all flights (black) and only periods when the aircraft altitude was below $3 \mathrm{~km}$ (red). The 20-30 s AMS-time series averaged data were used to determine the PDF. Both distributions peak in the bin spanning 175 to $180 \mathrm{~nm}$.

those observed over continental Europe or Liverpool, for example. The SLR-averaged observations do not show a strong east-west or north-south trend, though individual flights did show a slight decrease in the mean $\mathrm{rBC}$ size going from east to west over northern Europe. The rBC $D_{g m}$ values tended to decrease with increasing altitude (Fig. 5c). The studyaverage mean diameter for the lowest $500 \mathrm{~m}$ was approximately $185 \mathrm{~nm}$ compared to approximately $150 \mathrm{~nm}$ near the top of the boundary layer and $100 \mathrm{~nm}$ in the free troposphere. The probability density functions for $\mathrm{rBC}$ "core" $D_{g m}$ values measured at all altitudes and restricted to $<3 \mathrm{~km}$ are shown in Fig. 10.

The log-normal fits to the data provided some indication of the fraction of sub-micron mass falling outside the SP2 measurement range. Previous studies have used the difference between the area under the log-normal fit and the mass of $\mathrm{rBC}$ measured to scale $\mathrm{rBC}$ mass concentrations to account for the missing mass (e.g., Schwarz et al., 2006; Subramanian et al., 2010). As noted earlier, we did not apply such a correction to our reported $\mathrm{rBC}$ mass concentrations so that the results can be unambiguously related to the size range of the instrument. The scaling factor ranged from $\sim 1-1.2$ during the campaign, similar to that found by Schwarz et al. (2008a) for a similarly configured instrument. We stress this factor does not account for any contributions by particles in additional modes not represented by the log-normal fit to the data. 


\section{Discussion}

\subsection{Spatial distribution}

The lack of precipitation during the high pressure systemdominated period during LONGREX means that the air mass sampled to the west of continental Europe represented the integral of emissions into the airmass as it travelled across Europe. The rBC mass concentrations measured in this region therefore represent a polluted continental background for $\mathrm{rBC}$. The mean $\mathrm{rBC}$ mass concentration west of $3^{\circ} \mathrm{E}$ during this period was $140 \pm 50 \mathrm{ng} \mathrm{s} \mathrm{m}^{-3}$ ( \pm 1 standard deviation), within the range of continental background values reported by Schwarz et al. (2008a) based on SP2 measurements made over Texas. Shiraiwa et al. (2008) reported rBC mass concentrations measured by a ground-based SP2 of 230-510 $\mathrm{n} \mathrm{m}^{-3}$ in outflow from Japan, Korea and China, between 2-5 times larger than our measurements of European continental outflow. These figures are consistent with the Bond et al. (2004) emission inventory, which estimated rBC emissions from contained combustion in Asia (in 1996) were 4-5 times higher than those from Europe (Bond et al., 2004). Note that the previous SP2 studies used different multipliers to account for rBC not sampled by the SP2. We do not apply a scaling factor, but Schwarz et al. (2008a) apply a correction of 1.1 and Shiraiwa et al. (2008) use the lognormal integrated mass rather than the direct observations.

Modelling studies suggest $\mathrm{rBC}$ concentrations at the surface across Europe range from roughly $0.3-1.0 \mu \mathrm{g} \mathrm{m}^{-3}$ (Schaap et al., 2004; Marmer and Langmann, 2007; Tsyro et al., 2007). The global models included in the AeroCom aerosol model inter-comparison (http://nansen.ipsl.jussieu. fr/AEROCOM) tended to agree with surface observations in Europe, but overestimated rBC aloft (Koch et al., 2009). Evaluation of model results has been complicated by the variety of $\mathrm{rBC}$ definitions and their relationship to specific measurement techniques (Andreae and Gelencser, 2006; Bond and Bergstrom, 2006; Tsyro et al., 2007; Koch et al., 2009). Emission inventories used as model inputs are often based on different measurement methods than those used to evaluate the predicted mass concentrations (e.g., Vignati et al., 2010). Even if identical measurement approaches are used, artefacts can affect the results differently due to variable aerosol (e.g., dust, biomass burning emissions) and gas-phase volatile organic compound (VOC) properties.

The SLR-averaged rBC mass concentrations observed in this study are lower than the modelled surface EC concentrations of $0.3-1.0 \mu \mathrm{g} \mathrm{m}^{-3}$ over Europe reported by Tsyro et al. (2007), but they also reported their model results were similar to EC concentrations observed at six ground-based measurement locations. Differences in the ground and aircraft observations may reflect vertical gradients in concentrations, the seasonal variability in $\mathrm{rBC}$ emissions and differences in the $\mathrm{rBC}$ measurement method (SP2 versus filter OC/EC analysis). For example, Tsyro et al. (2007) use an EC
Table 3. Mean refractory black carbon (rBC) mass concentrations and mass geometric mean diameters ( \pm 1 standard deviation) measured by the SP2 aboard the FAAM aircraft and averaged over altitude bins for all flights.

\begin{tabular}{ccc}
\hline $\begin{array}{c}\text { Altitude range } \\
(\mathrm{km})\end{array}$ & $\begin{array}{c}\mathrm{rBC} \mathrm{mass}\left(\mathrm{ng} \mathrm{s} \mathrm{m}^{-3}\right) \\
(\mathrm{nm})\end{array}$ & $\begin{array}{c}\mathrm{D}_{g m} \\
(\mathrm{~nm})\end{array}$ \\
\hline 0.25 & $120 \pm 80$ & $180 \pm 15$ \\
$0.25-0.50$ & $90 \pm 60$ & $180 \pm 20$ \\
$0.50-0.75$ & $90 \pm 60$ & $180 \pm 15$ \\
$0.75-1.0$ & $90 \pm 50$ & $180 \pm 20$ \\
$1.0-1.5$ & $70 \pm 50$ & $180 \pm 15$ \\
$1.5-2.0$ & $50 \pm 60$ & $160 \pm 20$ \\
$2.0-2.5$ & $60 \pm 140$ & $160 \pm 30$ \\
$2.5-3.0$ & $4 \pm 7$ & $140 \pm 30$ \\
$3.0-3.5$ & $4 \pm 5$ & $140 \pm 50$ \\
$3.5-4$ & $7 \pm 7$ & $140 \pm 30$ \\
$4-5$ & $7 \pm 15$ & $130 \pm 30$ \\
$5-6$ & $3 \pm 2$ & $120 \pm 30$ \\
$6-7$ & $4 \pm 4$ & $130 \pm 40$ \\
$7-8$ & $5 \pm 4$ & $120 \pm 30$ \\
$8-9$ & $2 \pm 2$ & $110 \pm 20$ \\
\hline
\end{tabular}

emission inventory (Kupiainen and Klimont, 2007) that relies on thermo-optical methods. Despite the discrepancies in absolute concentrations, the spatial pattern of rBC observed during LONGREX (higher concentrations over northwestern Europe) was similar to the annually-averaged distribution predicted by Tsyro et al. (2007) and also observed in EC filter observations for the period July 2002 to June 2003.

There are several possible explanations for higher measured and modelled EC concentrations reported previously and our results. The model concentrations are averages of a two-year simulation from 2002-2004, while we report a snapshot of concentration measurements from the early summer and fall of 2008. Black carbon concentrations in Europe are generally lower in the summer due to the reduction of emissions from domestic wood burning (Tsyro et al., 2007). For example, wintertime EC concentrations in Europe were roughly a factor of 2 higher than those in the summer (Tsyro et al., 2007). Emission factors used by the model and the observations are based on EC measurements, which may be systematically higher or lower than $\mathrm{rBC}$ concentrations measured by the SP2, but there are currently no comparisons between SP2 observed rBC and filter-measured EC available to investigate this further. The filter data also sampled particles over a wider diameter range compared to the SP2, though this comparison is complicated by the mixing state of the particles and methods used to determine the rBC particle size.

Baumgardner et al. (2008) used an SP2 to observe $\mathrm{rBC}$ mass concentrations on the order of $1-3 \mathrm{ng} \mathrm{m}^{-3}$ (3$8 \mathrm{ng} \mathrm{s} \mathrm{m}^{-3}$ ) from $50^{\circ}-70^{\circ} \mathrm{N}$ over Europe. Their observations were restricted to altitudes above $9 \mathrm{~km}$, which is higher than the maximum altitude measured in this study. The average 
Table 4. Summary of regionally-averaged refractory black carbon (rBC) mass distribution statistics. MMD refers to the mass median diameter of the log-normal fit to the average size distribution, $\sigma_{g}$ is the width of the log-normal fit, and $D_{g m}$ is the average mass mean diameter calculated from Eq. (1). Regions are identified in Fig. 9

\begin{tabular}{lllccc}
\hline Date & Flight ID & Region & MMD (log-normal fit) & $\sigma_{g}$ (log-normal) & $D_{g m}(\mathrm{~nm})$ \\
\hline 16 April & B357 & A: Liverpool plume & 173 & 0.72 & 170 \\
21 May & B379 & C: Cabauw & 178 & 0.74 & 180 \\
14 May & B374 & B: Atlantic Ocean & 199 & 0.72 & 210 \\
23 September & B404 & D: Cranfield airport & 126 & 0.37 & 130 \\
\hline
\end{tabular}

rBC mass concentrations we measured at altitudes above $8 \mathrm{~km}$ were $2 \pm 2 \mathrm{ng} \mathrm{s} \mathrm{m}^{-3}$, consistent with the Baumgardner et al. (2008) observations. Schwarz et al. (2008b) also observed similar (within a factor of 2) rBC mass concentrations in the upper troposphere-lower stratosphere region in the tropics. No previous SP2-measured rBC mass concentration profiles have been reported over Europe, but the structure and magnitude of the $\mathrm{rBC}$ mass concentration profiles we observed were qualitatively similar to other $\mathrm{rBC}$ profiles measured using an SP2 over North America (Schwarz et al., 2006, 2008b,a; Spackman et al., 2008). We observed weaker $\mathrm{rBC}$ concentration gradients in the boundary layer compared to the North American studies, which is likely due to the well mixed boundary layer that was capped by the strong inversion during the high-pressure period during LONGREX. The high variability in $\mathrm{rBC}$ mass concentrations near the surface reflects the proximity to point sources encountered at low altitudes during most flights.

\subsection{Light absorption measurements and relationship to black carbon}

The FAAM aircraft uncorrected PSAP measurements were about $50 \%$ higher than the DLR Falcon data during the intercomparison flight, but agreed to within $20 \%$ after corrections were applied. Observations made from the two platforms in roughly the same locations during the campaign agreed to within $20-30 \%$. We make no claim that either measurement is the more accurate as both are subject to considerable uncertainties.

We have some confidence in the relative changes in absorption coefficients observed on both aircraft, but less so in the absolute accuracy of the measurements. The FAAM PSAP measurements were generally correlated with the SP2 $\mathrm{rBC}$ mass measurements, but the ratio of absorption to $\mathrm{rBC}$ mass (the mass absorption efficiency, MAE) was considerably higher than previous observations and theoretical predictions. Subramanian et al. (2010) found an average MAE of $13.1 \mathrm{~m}^{2} \mathrm{~g}^{-1}$ at $550 \mathrm{~nm}$ over Mexico using a PSAP and SP2 and Bond and Bergstrom (2006) recommend a MAE of $7.5 \pm 1.2 \mathrm{~m}^{2} \mathrm{~g}^{-1}$ at $550 \mathrm{~nm}$ for uncoated $\mathrm{rBC}$ particles. Coatings may enhance the MAE of $\mathrm{rBC}$, but the MAE values calculated for the PSAP and SP2 measurements on the
FAAM aircraft would require a coating enhancement on the order of at least $100-200 \%$ to be reconciled with literature values. Such enhancements are theoretically possible, but higher than previously reported and recommended (e.g., 3050\%, Bond et al., 2006; Schwarz et al., 2008b).

Mineral dust can also absorb light and may have been responsible for some of the additional observed absorption, however we believe the contribution by mineral dust to the PSAP observations was minor because the Rosemount inlets did not sample coarse $(>3 \mu \mathrm{m}$ ) aerosol efficiently (Haywood et al., 2003) and the contribution by the coarse mode particles (measured by the PCASP) to sub- $3 \mu \mathrm{m}$ volume was less than $30 \%$ in regions with high absorption coefficients. The estimated absorption by the $1-3 \mu \mathrm{m}$ particles typically measured by the PCASP was calculated assuming a conservative estimate of mineral dust MAE of $0.05 \mathrm{~m}^{2} \mathrm{~g}^{-1}$ (Clarke et al., 2004) and density of $2.5 \mathrm{~g} \mathrm{~cm}^{-3}$. The estimated absorption was between $10-20 \%$ of the total absorption measured by the PSAP. There was no correlation between the coarse mode estimated mass concentrations and increases in the absorption coefficient to $\mathrm{rBC}$ mass concentration ratio, which would be expected if mineral dust played a significant role in the absorption.

\subsection{Black carbon mass fractions}

The comparison of our results to $\mathrm{rBC}$ mass fractions measured previously is complicated by the variety of methods used to measure rBC and sub-micron aerosol mass and by possible reductions in $\mathrm{rBC}$ emissions during the time between our observation period and previous measurements and emission inventory compilations used in models. For example, Schwarz et al. (2006) converted SP2 measurements of non-rBC size distributions to total mass by scaling their SP2-measured volume observations to those measured by a forward cavity aerosol spectrometer. Shiraiwa et al. (2008) did not report rBC mass fractions, but they can be estimated from the reported AMS mass concentrations. Despite the different methods used to obtain $\mathrm{rBC}$ mass fractions, both of the studies observed $\mathrm{rBC}$ mass fractions ranging from $1-3 \%$ in the boundary layer, consistent with our observations in the UK and Europe. 
The pattern of relatively homogeneous $\mathrm{rBC}$ mass fractions has been observed previously in Europe using groundbased filter sampling methods. Putaud et al. (2004) found that $\mathrm{rBC}$ (measured using thermal-optical EC measurement techniques) represented $8 \%$ of non-kerbside PM2.5 measurements at 24 sites. The measurements included a number of "urban background" (defined as urban locations with fewer than 2500 vehicles/day within a $50 \mathrm{~m}$ radius) and "near city background" (defined as locations within 3-10 km of large pollution sources), as well as "natural background" sites at least $50 \mathrm{~km}$ from any major pollution sources. Despite observing a lower overall $\mathrm{rBC}$ mass loading, we found a similar result in that $\mathrm{rBC}$ mass fractions were not higher at "remote" locations over the Baltic Sea compared to observations in urban plumes. The only exception was the higher $\mathrm{rBC}$ mass fractions calculated assuming AMS mass in the Manchester/Liverpool plume, but this result was not observed when two higher estimates of sub-micron aerosol mass (derived from PCASP and SP2 scattering aerosol volume concentrations) were used to calculate $\mathrm{rBC}$ mass fractions. Shiraiwa et al. (2008) also found only small differences between rBC mass fractions measured in air masses originating from different sectors in east Asia, including maritime environments and the free troposphere. They observed highest $\mathrm{rBC}$ mass fractions in samples originating from the free troposphere $(2.6 \%)$ and lowest $\mathrm{rBC}$ mass fractions in marine samples $(1.4 \%)$, similar with range of values observed in this study.

Model calculations of EC mass fraction of $\mathrm{PM}_{2.5}$ over Europe predict regional background EC mass fractions vary from $3-7 \%$ across Europe, with higher mass fractions (7-15\%) observed in urban residential/commercial regions (Tsyro et al., 2007). The lower end of the model's urban residential/commercial range is similar to the maximum values we observed and also to previous SP2 $\mathrm{rBC}$ measurements in other locations, but its regional background values are about a factor of two higher than our observed values away from source regions. The model used by Tsyro et al. (2007) did not include secondary organic aerosol (SOA) contributions to total mass, however, and we believe secondary material, particularly ammonium nitrate, represented a substantial fraction of sub-micron aerosol mass measured in our study (Morgan et al., 2010a). The model mass fractions are therefore an upper estimate (Tsyro et al., 2007) consistent with our observations.

\subsection{Relationship to gas-phase species}

Morgan et al. (2010a) used $\mathrm{O}_{3} / \mathrm{NO}_{\mathrm{x}}$ ratios to divide the LONGREX and ADIENT data into five categories: near-urban $\left(0<\mathrm{O}_{3} / \mathrm{NO}_{\mathrm{x}}<0.1\right)$, near-source $\left(0.1<\mathrm{O}_{3} / \mathrm{NO}_{\mathrm{x}}<1\right)$, nearoutflow $\left(1<\mathrm{O}_{3} / \mathrm{NO}_{\mathrm{x}}<10\right)$, far-outflow $\left(10<\mathrm{O}_{3} / \mathrm{NO}_{\mathrm{x}}<50\right)$, and background $\left(50<\mathrm{O}_{3} / \mathrm{NO}_{\mathrm{x}}\right)$. We used the same classification scheme to examine $\mathrm{rBC}$ mass concentrations, $b_{a p}$ and the $\mathrm{rBC} / \triangle \mathrm{CO}$ ratios observed. The results are shown as a whisker plot in Fig. 11. The mean, median, and range of observed rBC mass concentrations shown in Fig. 11a generally decreased going from near-urban (lowest $\mathrm{O}_{3} / \mathrm{NO}_{\mathrm{x}}$ ratios) to background conditions (highest $\mathrm{O}_{3} / \mathrm{NO}_{\mathrm{x}}$ ratios). Aerosol light absorption (Fig. 11b) follows a similar pattern, except that the highest observations typically fell in the near-source classification rather than the near-urban classification. Its possible that $b_{a p}$ initially increases as $\mathrm{rBC}$ becomes mixed with additional aerosol species, leading to an enhancement in light absorption or increased PSAP artefacts. We investigate this phenomenon in detail in the companion manuscript examining rBC mixing state (McMeeking et al., 2010).

The $\mathrm{rBC} / \triangle \mathrm{CO}$ ratios displayed the opposite trend observed for $\mathrm{rBC}$ mass concentrations and $b_{a p}$, increasing with increasing distance from source (Fig. 11c). The lowest ratios were observed for the near-urban air mass classification and the highest ratios were observed for the far-outflow and background classifications. This finding was consistent with the flight-averaged and SLR-averaged results discussed previously, where we observed lower ratios near source regions over the English Channel and Cabauw region and higher ratios off of the east coast of the UK and over northern Germany.

The European results are consistent with previous studies comparing $\mathrm{CO}$ to SP2-measured $\mathrm{rBC}$ mass concentrations. Spackman et al. (2008) report an average SP2measured $\mathrm{rBC} / \triangle \mathrm{CO}$ ratio of $6.8 \mathrm{ng} \mathrm{rBC} \mathrm{s} \mathrm{m}^{-3} \mathrm{ppbv}^{-1} \mathrm{CO}$ for urban/industrial outflow in Texas. We adjusted their reported value of $5.8 \mathrm{ng} \mathrm{rBC} \mathrm{kg}^{-1}$ dry air to $\mathrm{ng} \mathrm{rBC} \mathrm{s} \mathrm{m}^{-3}$ and removed the 1.1 multiplying factor Spackman et al. (2008) used to scale the rBC mass concentrations. Their observed $\mathrm{rBC} / \triangle \mathrm{CO}$ ratio agrees well with the England east coast flight (B356) and others in near-outflow to background air mass classifications. Baumgardner et al. (2007) reported an $\mathrm{rBC} / \mathrm{CO}$ ratio of $1.0 \mathrm{ng} \mathrm{rBC} \mathrm{m}^{-3} \mathrm{ppbv}^{-1} \mathrm{CO}(1.4 \mathrm{ng}$ $\mathrm{rBC} \mathrm{s} \mathrm{m}^{-3} \mathrm{ppbv}^{-1} \mathrm{CO}$ adjusted to STP assuming measurement made at $780 \mathrm{hPa}$ and $290 \mathrm{~K}$ ) for ground-based measurements in Mexico City. Subramanian et al. (2010) observed a higher average ratio of $2.9\left(\mathrm{ng} \mathrm{s} \mathrm{m}^{-3}\right)$ over Mexico.

Differences in removal rates and emission sources are often used to explain differences in $\mathrm{rBC} / \Delta \mathrm{CO}$ ratios. Kirchstetter et al. (1999) found the $\mathrm{rBC} / \triangle \mathrm{CO}$ ratio depended on the fraction of heavy-duty vehicles in use compared to other vehicle types. The shorter lifetime of $\mathrm{rBC}$ due to cloud and precipitation scavenging compared to $\mathrm{CO}$ means that the $\mathrm{rBC} / \triangle \mathrm{CO}$ ratio should decrease with time. Dickerson et al. (2002) suggested different $\mathrm{rBC}$ removal lifetimes in the free troposphere and marine boundary layer could explain the roughly doubled $\mathrm{rBC} / \triangle \mathrm{CO}$ ratios they observed from an aircraft compared to a ship-based measurement during the Indian Ocean Experiment (INDOEX). Photochemical processing of volatile organic compounds and methane also leads to $\mathrm{CO}$ production on longer time-scales (e.g., Seinfeld and Pandis, 2006), which will also decrease the $\mathrm{rBC} / \Delta \mathrm{CO}$ ratio with increasing time and distance from source. Our observations in Europe, however, show that the lowest $\mathrm{rBC} / \Delta \mathrm{CO}$ 

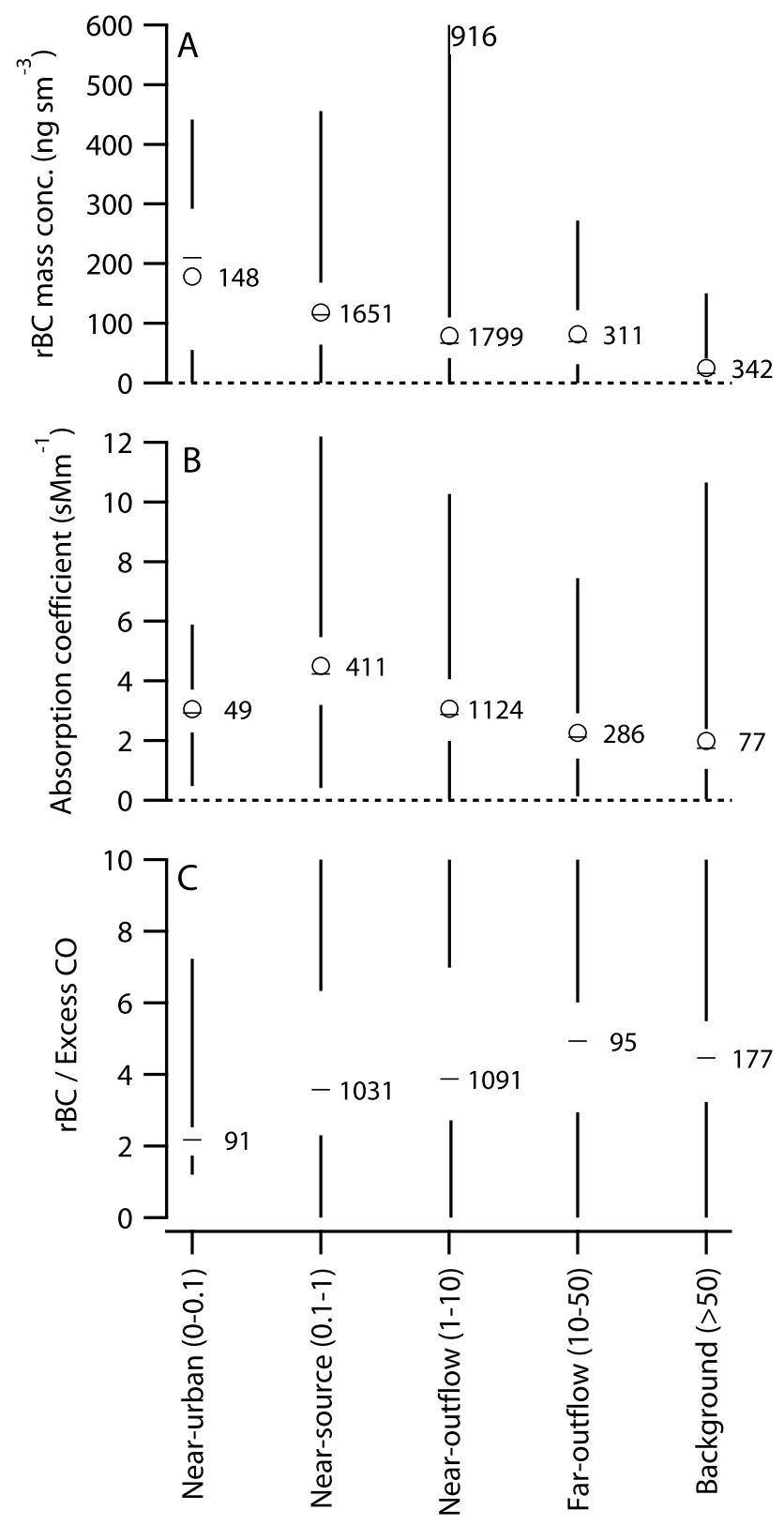

Fig. 11. Whisker plots showing the mean (circles), median (horizontal dash), minimum, maximum, 25th and 75th percentiles (vertical lines) classified by air mass type for (a) refractory black carbon (rBC) mass, (b) light absorption coefficient at $550 \mathrm{~nm}$, and (c) ratio of $\mathrm{rBC}$ to excess carbon monoxide mixing ratios $\left(\mathrm{ng} \mathrm{s} \mathrm{m}^{-3} / \mathrm{ppbv}\right.$ ). Air masses are defined using ratios of $\mathrm{O}_{3} / \mathrm{NO}_{\mathrm{x}}$ (listed with air mass label) following Morgan et al. (2010a). The number of individual data points in each bin are given to the right of the data. Maximum $\mathrm{rBC} / \mathrm{CO}$ ratios are truncated to 10 and only median values are shown due to bias from high ratios associated with variability in the $\mathrm{rBC} / \mathrm{CO}$ ratios.

ratios were observed near major source regions, and that higher ratios were observed in more chemically processed air masses. High $\mathrm{rBC} / \triangle \mathrm{CO}$ ratios were associated with regions of high ozone concentrations relative to $\mathrm{NO}_{\mathrm{x}}$. A factor analysis of the organic aerosol loadings observed by the AMS showed enhanced oxidized organic aerosol concentrations in the same regions (Morgan et al., 2010a). These observations support the conclusion that the different $\mathrm{rBC} / \triangle \mathrm{CO}$ ratios observed in this study are attributable to differences in emission sources (particularly vehicle fleets and industrial sources) rather than $\mathrm{rBC}$ or $\mathrm{CO}$ processing and removal mechanisms.

\subsection{Black carbon size distributions}

Prior to the development of the SP2, information regarding rBC size relied on filter and cascade impactor techniques (e.g., Kleeman et al., 2000; Putaud et al., 2004; Hitzenberger et al., 2006). Comparing SP2 data to filter and cascade impactor data is not straight forward, however, because the offline techniques segregate particles on the basis of their aerodynamic diameter, which depends not only on the rBC mass, but also on the amount of material mixed with each $\mathrm{rBC}$ "core". The SP2 quantifies mass of the $\mathrm{rBC}$ core. In this sense, the impactor and filter data represent upper-limits to the expected $\mathrm{rBC}$ distribution range. Filter and impactor data show the vast majority of $\mathrm{rBC}$ mass is associated particles in the sub-micron or $\mathrm{PM}_{2.5}$ (particulate matter below $2.5 \mu \mathrm{m}$ aerodynamic diameter) size range (e.g., Kleeman et al., 2000; Putaud et al., 2004). For example, Hitzenberger et al. (2006) found $\mathrm{rBC}$ measured in Vienna, Austria could be represented by a log-normal distribution with a mass median aerodynamic diameter of $0.38 \mu \mathrm{m}$. Clarke et al. (2004) combined an optical sizing method with a thermal/volatility approach to measure a log-normally distributed $\mathrm{rBC}$ size distribution centred at $0.27 \mu \mathrm{m}$ in Asian outflow. Both of these figures are higher than the most frequently observed $\mathrm{rBC}$ geometric mean mass diameter of $175-180 \mathrm{~nm}$ reported here, but we stress we report the mean size of the $\mathrm{rBC}$ "core" and not the mixed particle. We investigate the size dependence of the mixed particles in a companion manuscript focusing on particle mixing state (McMeeking et al., 2010). Recent SP2-based studies have greatly increased the number of rBC size distribution observations available. We summarize existing SP2 observations in Table 5 together with our European observations. The results from different SP2 studies are somewhat complicated by the application of different $\mathrm{rBC}$ densities when converting from $\mathrm{rBC}$ mass to $\mathrm{rBC}$ diameter, different effective instrument size ranges, and different and in some cases ambiguous parameters used to report the mean size for a given $\mathrm{rBC}$ mass size distribution. Differences in $\mathrm{rBC}$ size arising from the assumed $\mathrm{rBC}$ density scale only as the cube root of the ratio of the densities. The choice of mean size parameter and calculation method is more difficult to quantify and will depend on the size distribution, but in our study we observed differences on the order of 10-20 nm between the MMD obtained by log-normal fitting and geometric mean diameters calculated directly from the measured size distributions, so we would expect a similar 
Table 5. Summary of refractory black carbon (rBC) mass size distributions measured by the SP2 in the boundary layer over Europe and for selected previous studies. If available, the standard deviation corresponding to the average of mean sizes observed is also reported. The mean diameters adjusted for an assumed $\mathrm{rBC}$ density of $1.8 \mathrm{~g} \mathrm{~cm}^{-3}$ are also given.

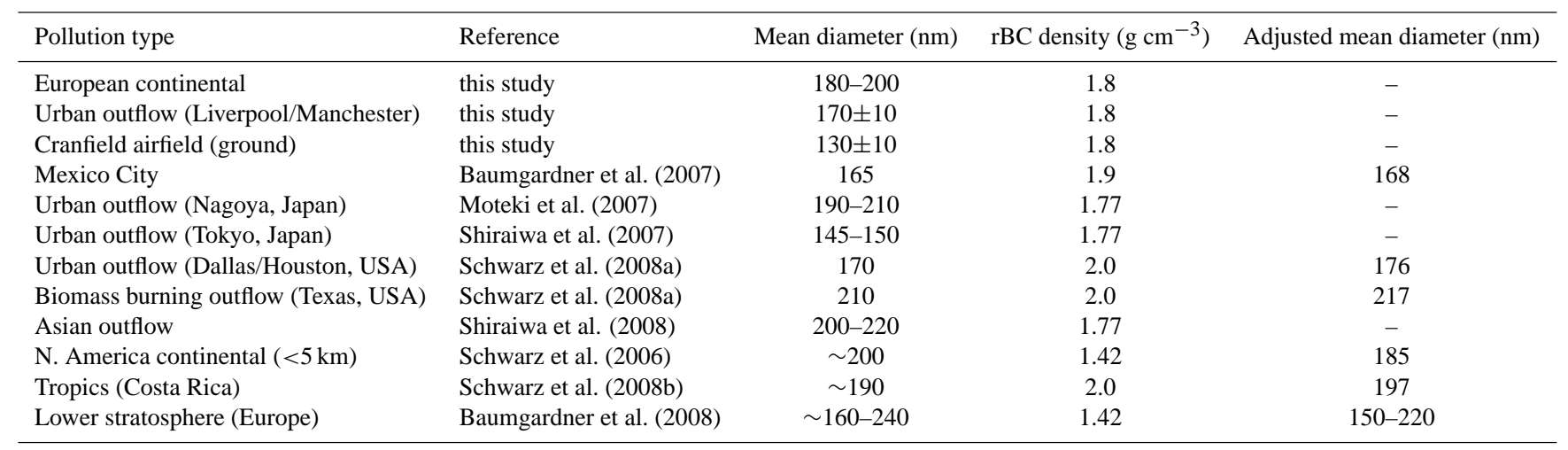

spread in other data sets. Despite these differences, there is a growing consensus that the ambient $\mathrm{rBC}$ mass distribution can be described by a log-normal distribution centred at approximately $200 \mathrm{~nm}$ (Schwarz et al., 2006, 2008a,b; Shiraiwa et al., 2007, 2008; Subramanian et al., 2010).

Previous studies have generally found larger rBC mass mean diameters for older and/or more processed $\mathrm{rBC}$ in aged plumes and continental pollution (Schwarz et al., 2006; Moteki et al., 2007; Shiraiwa et al., 2008) and smaller mean diameters closer to source (Baumgardner et al., 2007; Shiraiwa et al., 2007; Schwarz et al., 2008a). These findings are also supported by our observations of smaller $\operatorname{rBC} D_{g m}$ in urban plumes and near source regions compared to the continental scale values. We are unaware of any SP2-based direct source sampling of engine exhaust or other industrial $\mathrm{rBC}$ sources, but Baumgardner et al. (2007) report mean rBC diameters observed in Mexico City in a location dominated by traffic sources of approximately $165 \mathrm{~nm}$. The fresh Cranfield airfield jet engine/GPU emission rBC $D_{g m}$ values are about $30 \mathrm{~nm}$ smaller than the Mexico City data, but represent an even fresher source of rBC. The difference may also be due to the presence of jet engine emissions in the vicinity of the airfield.

Other combustion sources, particularly biomass burning or industrial emissions may emit larger rBC size distributions, but to date no measurements have been made near such sources. We assume the larger rBC mean diameters observed on regional scales in our data and previous studies result from coagulation and ageing processes. There is evidence from previous SP2 measurements showing the mean $\mathrm{rBC}$ size increases with photochemical age. Moteki et al. (2007) observed an increase in $\mathrm{rBC}$ mass median diameters from 190 to $210 \mathrm{~nm}$ for 2-h and 14-h old outflow from the Nagoya urban area in Japan. Though we lacked the ability to determine the photochemical age of the air masses sampled during out study, our observations in air masses with the largest highly- oxidized organic aerosol fraction (Morgan et al., 2010a) also had the largest mean $\mathrm{rBC}$ mass diameters.

The relationship between $\mathrm{rBC}$ size distributions and altitude is less clear compared to other rBC properties observed previously, though there are few reported observations of $\mathrm{rBC}$ as a function of altitude. Schwarz et al. (2006) found smaller $\mathrm{rBC}$ number distributions below $5 \mathrm{~km}$ compared to above $10 \mathrm{~km}$ (there was little difference for mass distributions). Schwarz et al. (2008b) did not observe a clear shift in $\mathrm{rBC}$ size (in terms of mass) when comparing $\mathrm{rBC}$ samples in the lower troposphere and lower stratosphere over Costa Rica in 2006. We observed a clear shift in $D_{g m}$ (shown in Fig. 5) for $\mathrm{rBC}$ observed at the upper range of the altitudes covered during the campaign. The observed values are significantly lower than the values of 160-240 nm observed over Europe in the lower stratosphere reported by Baumgardner et al. (2008). The representativeness of our upper troposphere observations is unknown, however, given that most of our observations at higher altitudes are from flights during the April and September ADIENT flights.

There are no reported profiles of $\mathrm{rBC}$ mean size to which we can compare our observations, so it is difficult to evaluate their representativeness. Cloud and precipitation scavenging are thought to be the dominant removal mechanisms for rBC, so it is possible that larger $\mathrm{rBC}$ particles are more efficiently scavenged by clouds and precipitation as they transported vertically. One complication is that the $\mathrm{rBC}$ core diameter is probably not the most relevant parameter for determining the efficiency of cloud and precipitation removal, rather it is the diameter of the mixed particle. We investigate this further in a related manuscript investigating the $\mathrm{rBC}$ mixing state (McMeeking et al., 2010). Black carbon above the boundary layer in regions with little convective influence is likely more aged (e.g., Schwarz et al., 2008b), so we would expect larger rBC mean sizes based on other observations, including those reported here and by Moteki et al. (2007). Another 
possibility is that the $\mathrm{rBC}$ observed at higher altitudes has a stronger influence from fresh aviation emissions, although a previous SP2-based study (Baumgardner et al., 2008) did not find evidence that aircraft emissions were a significant source of rBC over Europe. Hendricks et al. (2004) also found little evidence of a significant contribution by aircraft to $\mathrm{rBC}$ mass concentrations in the upper troposphere, even in flight corridors.

\section{Conclusions}

We have presented the first SP2-based measurements of $\mathrm{rBC}$ concentrations and properties in the lower troposphere over Europe. Run-averaged rBC mass concentrations in the boundary layer $(<3 \mathrm{~km})$ ranged from roughly $300 \mathrm{ng} \mathrm{s} \mathrm{m}^{-3}$ in near-urban regions to $50 \mathrm{ng} \mathrm{s} \mathrm{m}^{-3}$ in background environments, consistent with previous SP2 observations in polluted continental regions in Asia and North America. The aircraft observations were lower than measured and modelled surface rBC mass concentrations, but the comparison was complicated by both variability in measurement times and locations and by differences in the rBC measurement method, the latter highlighting the need for a systematic comparison of SP2 measurements to filter-based OC/EC approaches. Spatially, rBC mass concentrations increased from the eastern to western limits of the measurement region during a period dominated by easterly flow. rBC mass concentrations in the boundary layer were more than a factor of 10 higher than in the lower free troposphere, decreasing on average from about 100 to $5 \mathrm{ng} \mathrm{s} \mathrm{m}^{-3}$.

The rBC fraction of sub-micron mass was between 0.5$3 \%$ and displayed a weak geographic dependence. Higher rBC concentrations in northwestern Europe were balanced by increases in non-rBC mass, primarily ammonium nitrate and organic aerosol. The $\mathrm{rBC} / \triangle \mathrm{CO}$ ratio in urban outflow and near emission sources was approximately $1 \mathrm{ng} \mathrm{s} \mathrm{m}^{-3} / \mathrm{ppbv}$ compared $5 \mathrm{ng} \mathrm{s} \mathrm{m}^{-3} / \mathrm{ppbv}$ over the Baltic Sea over continental Europe and on average it increased with increasing $\mathrm{O}_{3} / \mathrm{NO}_{\mathrm{x}}$. The geometric mass mean diameter of rBC "core" mass distributions was slightly higher for European continental pollution (180-200 nm) compared to urban outflow $(170 \pm 10 \mathrm{~nm})$ and about $50 \%$ higher than rBC mass distributions measured on the ground at the FAAM aircraft base in the UK $(130 \pm 10 \mathrm{~nm})$. The $\mathrm{rBC} / \triangle \mathrm{CO}$ and $\mathrm{rBC}$ "core" mass distribution results were consistent with previous SP2 measurements over North America and Asia dominated by anthropogenic sources.

The PSAP-based absorption measurements made on two aircraft platforms displayed a similar spatial pattern to the SP2 rBC mass measurements, but differed by at least a factor of two in total light absorption coefficients. Some of the discrepancy was due to the different operating regions and altitudes probed by the aircraft, but the PSAP measurements differed even during a wingtip-to-wingtip intercom- parison flight, though this took place in relatively low-rBC conditions. A direct comparison between SP2-measured rBC mass and PSAP-measured absorption showed that absorption measurements were at least a factor of two higher than those predicted by typical rBC mass absorption efficiencies and higher than previous aircraft-based SP2-PSAP comparisons. These results highlight the need for improved airborne aerosol absorption measurements and indicate that airborne PSAP-based estimates of rBC mass should be viewed with caution. A similar comparison between SP2 rBC mass measurements on separate aircraft would help to identify if the different measurements are arising purely from the rBC measurement method or other factors.

Our results add to the observational dataset necessary for the evaluation of modelled $\mathrm{rBC}$ concentrations and properties, including rBC "core" size distributions. The observations span a large range of concentrations, altitudes and source regions over Europe, a significant global rBC source and densely populated region. Not surprisingly, the different methods available for determining rBC mass concentrations greatly complicated attempts to compare our observations to previous measurements and model predictions, and future evaluations will also struggle until more systematic comparisons of SP2 observations to other $\mathrm{rBC}$ and $\mathrm{EC}$ measurement methods are performed.

\section{Supplementary material related to this article is available online at: http://www.atmos-chem-phys.net/10/9393/2010/ acp-10-9393-2010-supplement.pdf..}

Acknowledgements. The ADIENT and LONGREX projects were supported by the Natural Environment Research Council ADIENT project NE/E011101/1 and EUCAARI project 036833-2. W. Morgan was supported by NERC studentship NER/S/A/2006/14040 and a CASE sponsorship from Aerodyne Research Inc. The NERC National Centre for Atmospheric Sciences (NCAS) Facility for Ground Atmospheric Measurements (FGAM) supported the maintenance of the cTOF-AMS. We thank Yutaka Kondo and Nobuhiro Moteki for providing Aquadag effective density data. We thank F. Abicht, K. N. Bower, C. L. Ryder, A. Stohl and P. I. Williams for their contributions to the project. The Facility for Airborne Atmospheric Measurements is jointly managed by the National Centre for Atmospheric Sciences on behalf of the Natural Environment Research Council and the Met Office and we are grateful to their staff for its operation throughout this study. We also thank the Avalon, DLR-Falcon and DirectFlight personnel for their work during the campaign. ECMWF reanalysis data were provided by the ERA-Interim data extraction tool. We thank M. Shiraiwa and an anonymous reviewer for their comments on the manuscript. In memory of Keith Drummond.

Edited by: V.-M. Kerminen 


\section{References}

Anderson, T. L., Covert, D. S., Marshall, S. F., Laucks, M. L., Charlson, R. J., Waggoner, A. P., Ogren, J. A., Caldow, R., Holm, R. L., Quant, F. R., Sem, G. J., Wiedensohler, A., Ahlquist, N. A., and Bates, T. S.: Performance characteristics of a high-sensitivity, three-wavelength, total scatter/backscatter nephelometer, J. Atmos. Ocean. Technol., 13, 967-986, 1996.

Andreae, M. O. and Gelencser, A.: Black carbon or brown carbon? The nature of light-absorbing carbonaceous aerosols, Atmos. Chem. Phys., 6, 3131-3148, doi:10.5194/acp-6-3131-2006, 2006.

Baumgardner, D., Subramanian, R., Twohy, C., Stith, J., and Kok, G.: Scavenging of black carbon by ice crystals over the northern Pacific, Geophys. Res. Lett., 35, L22815, doi: 10.10292008GL035764, 2008.

Baumgardner, D., Kok, G., and Raga, G.: Warming of the Arctic lower stratosphere by light absorbing particles, Geophysical Research Letters, 31, L06117, doi:10.1029/2003GL018883, 2004.

Baumgardner, D., Kok, G. L., and Raga, G. B.: On the diurnal variability of particle properties related to light absorbing carbon in Mexico City, Atmos. Chem. Phys., 7, 2517-2526, doi:10.5194/acp-7-2517-2007, 2007.

Baumgardner, D., Kok, G., Kraemer, M., and Weidle, F.: Meridional gradients of light absorbing carbon over northern Europe, Environ. Res. Lett., 3, 025010, doi:10.1088/1748-9326/3/ 2/025010, 2008.

Bond, T. C. and Bergstrom, R. W.: Light absorption by carbonaceous particles: An investigative review, Aerosol Sci. Technol., 40, 27-67, 382, 2006.

Bond, T. C., Anderson, T. L., and Campbell, D.: Calibration and intercomparison of filter-based measurements of visible light absorption by aerosols, Aerosol Sci. Technol., 30, 582-600, 1999.

Bond, T. C., Streets, D. G., Yarber, K. F., Nelson, S. M., Woo, J. H., and Klimont, Z.: A technology-based global inventory of black and organic carbon emissions from combustion, J. Geophys. Res.-Atmos., 109, doi:10.1029/2003JD003697, 2004.

Bond, T. C., Habib, G., and Bergstrom, R. W.: Limitations in the enhancement of visible light absorption due to mixing state, Journal of Geophysical Research-Atmospheres, 111, 13, D20211, doi: 10.1029/2006JD007315, 2006.

Canagaratna, M. R., Jayne, J. T., Jimenez, J. L., Allan, J. D., Alfarra, M. R., Zhang, Q., Onasch, T. B., Drewnick, F., Coe, H., Middlebrook, A., Delia, A., Williams, L. R., Trimborn, A. M., Northway, M. J., DeCarlo, P. F., Kolb, C. E., Davidovits, P., and Worsnop, D. R.: Chemical and microphysical characterization of ambient aerosols with the aerodyne aerosol mass spectrometer, Mass Spectrom. Rev., 26, 185-222, 2007.

Cappa, C. D., Lack, D. A., Burkholder, J. B., and Ravishankara, A. R.: Bias in filter-based aerosol light absorption measurements due to organic aerosol loading: Evidence from laboratory measurements, Aerosol Sci. Technol., 42, 1022-1032, 2008.

Chow, J., Doraiswamy, P., Watson, J., Chen, L.-W., Ho, S., and Sodeman, D.: Advances in integrated and continuous measurements for particle mass and chemical composition, J. Air Waste Manage. Assoc., 58, 141-163, doi:10.3155/1047-3289.58.2.141, 2008.

Clarke, A. D., Shinozuka, Y., Kapustin, V. N., Howell, S., Huebert, B., Doherty, S., Anderson, T., Covert, D., Anderson, J., Hua, X., Moore, K. G., McNaughton, C., Carmichael, G., and Weber, R.:
Size distributions and mixtures of dust and black carbon aerosol in Asian outflow: Physiochemistry and optical properties, J. Geophys. Res., 109, 1-20, doi:10.1029/2003JD004378, 2004.

Cross, E., Slowik, J., Davidovits, P., Allan, J., Worsnop, D., Jayne, J., Lewis, D., Canagaratna, M., and Onasch, T.: Laboratory and ambient particle density determinations using light scattering in conjunction with aerosol mass spectrometry, Aerosol Sci. Technol., 41, 343-359, 2007.

Dickerson, R. R., Andreae, M. O., Campos, T., Mayol-Bracero, O. L., Neusuess, C., and Streets, D. G.: Analysis of black carbon and carbon monoxide observed over the Indian Ocean: Implications for emissions and photochemistry, J. Geophys. Res.Atmos., 107, 8017, doi:10.1029/2001JD000501, 2002.

Drewnick, F., Hings, S. S., DeCarlo, P., Jayne, J. T., Gonin, M., Fuhrer, K., Weimer, S., Jimenez, J. L., Demerjian, K. L., Borrmann, S., and Worsnop, D. R.: A new time-of-flight aerosol mass spectrometer (TOF-AMS) - Instrument description and first field deployment, Aerosol Sci. Technol., 39, 637-658, 2005.

Ehara, K., Hagwood, C., and Coakley, K.: Novel method to classify aerosol particles according to their mass-to-charge ratio: Aerosol particle mass analyser, J. Aerosol Sci., 27, 217-234, 1996.

Esselborn, M., Wirth, M., Fix, A., Tesche, M., and Ehret, G.: Airborne high spectral resolution lidar for measuring aerosol extinction and backscatter coefficients, Appl. Optics, 47, 346-358, 2008.

Feldpausch, P., Fiebig, M., Fritzsche, L., and Petzold, A.: Measurement of ultrafine aerosol size distributions by a combination of diffusion screen separators and condensation particle counters, J. Aerosol Sci., 37, 577-597, doi:10.1016/j.jaerosci.2005.04.009, 2006.

Foltescu, V. L., Selin, E., and Below, M.: Corrections for particle losses and sizing errors during aircraft aerosol sampling using a rosemount inlet and the PMS LAS-X, Atmos. Environ., 29, 449453, 1995.

Gao, R. S., Hall, S. R., Swartz, W. H., Schwarz, J. P., Spackman, J. R., Watts, L. A., Fahey, D. W., Aikin, K. C., Shetter, R. E., and Bui, T. P.: Calculations of solar shortwave heating rates due to black carbon and ozone absorption using in situ measurements, J. Geophys. Res., 113, D14203, doi:10.1029/2007JD009358, 2008.

Gao, R. S., Schwarz, J. P., Kelly, K. K., Fahey, D. W., Watts, L. A., Thompson, T. L., Spackman, J. R., Slowik, J. G., Cross, E. S., Han, J. H., Davidovits, P., Onasch, T. B., and Worsnop, D. R.: A novel method for estimating light-scattering properties of soot aerosols using a modified single-particle soot photometer, Aerosol Sci. Technol., 41, 125-135, doi:10.1080/ $02786820601118398,2007$.

Hamburger, T., McMeeking, G., Miniken, A., Birmili, W., Dall'Osto, M., O’Dowd, C., Flentje, H., Henzing, B., Junninen, H., Kristensson, A., de Leeuw, G., Stohl, A., Burkhart, J. F., Coe, H., Krejci, R., and Petzold, A.: Overview of the synoptic and pollution situation over Europe during the EUCAARI-LONGREX field campaign, Atmos. Phys. Chem. Discuss., 10, 19129-19174, doi:10.5194/acpd-10-19129-2010, 2010.

Haywood, J. M., Osborne, S. R., Francis, P. N., Keil, A., Formenti, P., Andreae, M. O., and Kaye, P. H.: The mean physical and optical properties of regional haze dominated by biomass burning aerosol measured from the C-130 aircraft during SAFARI 2000, J. Geophys. Res., 108, 8473, doi:10.1029/2002JD002226, 2003. Hendricks, J., Kärcher, B., Döpelheuer, A., Feichter, J., Lohmann, 
U., and Baumgardner, D.: Simulating the global atmospheric black carbon cycle: a revisit to the contribution of aircraft emissions, Atmos. Chem. Phys., 4, 2521-2541, doi:10.5194/acp-42521-2004, 2004.

Hitzenberger, R., Ctyroky, P., Berner, A., Tursic, J., Podkrajsek, B., and Grgic, I.: Size distribution of black (rBC) and total carbon (TC) in Vienna and Ljubljana, Chemosphere, 65, 2106-2113, doi:10.1016/j.chemosphere.2006.06.042, 2006.

Jacob, D. J., Crawford, J. H., Maring, H., Clarke, A. D., Dibb, J. E., Ferrare, R. A., Hostetler, C. A., Russell, P. B., Singh, H. B., Thompson, A. M., Shaw, G. E., McCauley, E., Pederson, J. R., and Fisher, J. A.: The ARCTAS aircraft mission: design and execution, Atmos. Chem. Phys. Discuss., 9, 17073-17123, doi:10.5194/acpd-9-17073-2009, 2009.

Jacobson, M. Z.: Climate response of fossil fuel and biofuel soot, accounting for soot's feedback to snow and sea ice albedo and emissivity, J. Geophys. Res., 109, 1-15, doi:10.1029/ 2004JD004945, 2004.

Kirchstetter, T. W., Harley, R. A., Kreisberg, N. M., Stolzenburg, M. R., and Hering, S. V.: On-road measurement of fine particle and nitrogen oxide emissions from light- and heavy-duty motor vehicles, Atmos. Environ., 33, 2955-2968, 1999.

Kirchstetter, T. W., Corrigan, C. E., and Novakov, T.: Laboratory and field investigation of the adsorption of gaseous organic compounds onto quartz filters, Atmos. Environ., 35(13), 1663-1671, , 2001.

Kleeman, M. J., Schauer, J. J., and Cass, G. R.: Size and composition distribution of fine particulate matter emitted from motor vehicles, Environmental Sci. Technol., 34, 1132-1142, 2000.

Koch, D., Schulz, M., Kinne, S., McNaughton, C., and Spackman, J. R.: Evaluation of black carbon estimations in global aerosol models, Atmos. Chem. Phys., 9, 9001-9026, doi:10.5194/acp-99001-2009, 2009.

Kulmala, M., Asmi, A., Lappalainen, H. K., Carslaw, K. S., Poschl, U., Baltensperger, U., Hov, O., Brenquier, J.-L., Pandis, S. N., Facchini, M. C., Hansson, H.-C., Wiedensohler, A., and O'Dowd, C. D.: Introduction: European Integrated Project on Aerosol Cloud Climate and Air Quality interactions (EUCAARI) - integrated aerosol research from nano to global scales, Atmos. Chem. Phys., 9, 2825-2841, doi:10.5194/acp-9-2825-2009, 2009.

Kupiainen, K. and Klimont, Z.: Primary emissions of fine carbonaceous particles in Europe, Atmos. Environ., 41, 2156-2170, 2007.

Lack, D. A., Cappa, C. D., Covert, D. S., Baynard, T., Massoli, P., Sierau, B., Bates, T. S., Quinn, P. K., Lovejoy, E. R., and Ravishankara, A. R.: Bias in filter-based aerosol light absorption measurements due to organic aerosol loading: Evidence from ambient measurements, Aerosol Sci. Technol., 42, 1033-1041, doi:10.1080/02786820802389277, 2008.

Marmer, E. and Langmann, B.: Aerosol modeling over Europe: 1. Interannual variability of aerosol distribution, J. Geophys. Res.Atmos., 112, D23S15, doi:10.1029/2006JD008113 2007.

Menon, S., Hansen, J., Nazarenko, L., and Luo, Y.: Climate effects of black carbon aerosols in China and India, Science, 297, 22502253, doi:10.1126/science.1075159, 2002.

Morgan, W. M., Allan, J. D., Bower, K. N., Capes, G., Crosier, J., Williams, P. I., and Coe, H.: Vertical distribution of sub-micron aerosol chemical composition from North-Western Europe and the North-East Atlantic, Atmos. Chem. Phys., 9, 5389-5401, doi:10.5194/acp-9-5389-2009, 2009.

Morgan, W., Allan, J. D., Bower, K. N., Highwood, E. J., Liu, D., McMeeking, G. R., Northway, M. J., Williams, P. I., Krejci, R., and Coe, H.: Airborne measurements of the spatial distribution of aerosol chemical composition across Europe and evolution of the organic fraction, Atmos. Chem. Phys., 10, 4065-4083, doi:10.5194/acp-10-4065-2010, 2010a.

Morgan, W. T., Allan, J. D., Bower, K. N., Esselborn, M., Harris, B., Henzing, J. S., Highwood, E. J., Kiendler-Scharr, A., McMeeking, G. R., Mensah, A. A., Northway, M. J., Osborne, S., Williams, P. I., Krejci, R., and Coe, H.: Enhancement of the aerosol direct radiative effect by semi-volatile aerosol components: airborne measurements in North-Western Europe, Atmos. Chem. Phys., 10, 8151-8171, doi:10.5194/acp-10-8151-2010, 2010b.

Moteki, N. and Y. Kondo, Dependence of laser-induced incandescence on physical properties of black carbon aerosols: Measurements and theoretical interpretation, Aerosol Sci. Technol., 44, 663-675, 2010.

Moteki, N., Kondo, Y., Miyazaki, Y., Takegawa, N., Komazaki, Y., Kurata, G., Shirai, T., Blake, D. R., Miyakawa, T., and Koike, M.: Evolution of mixing state of black carbon particles: Aircraft measurements over the western Pacific in March 2004, Geophys. Res. Lett., 34, L11803, doi:10.1029/2006GL028943, 2007.

Moteki, N., Kondo, Y., and Nakamura, S.-I.: Method to measure refractive indices of small nonspherical particles: Application to black carbon particles, J. Aerosol Sci., 41, 513-521, doi:10.1016/ j.jaerosci.2010.02.013, 2010.

Ogren, J.: Comment on Calibration and Intercomparison of FilterBased Measurements of Visible Light Absorption by Aerosols, Aerosol Sci. Technol., 44, 589-591, 2010.

Osborne, S. R., Haywood, J. M., and Bellouin, N.: In situ and remote-sensing measurements of the mean microphysical and optical properties of industrial pollution aerosol during ADRIEX, Q. J. Roy. Meteorol. Soc., 133, 17-32, 2007.

Petzold, A., Weinzierl, B., Huntrieser, H., Stohl, A., Real, E., Cozic, J., Fiebig, M., Hendricks, J., Lauer, A., Law, K., Roiger, A., Schlager, H., and Weingartner, E.: Perturbation of the European free troposphere aerosol by North American forest fire plumes during the ICARTT-ITOP experiment in summer 2004, Atmos. Chem. Phys., 7, 5105-5127, doi:10.5194/acp-7-51052007, 2007.

Putaud, J. P., Raes, F., Van Dingenen, R., Bruggemann, E., Facchini, M. C., Decesari, S., Fuzzi, S., Gehrig, R., Huglin, C., Laj, P., Lorbeer, G., Maenhaut, W., Mihalopoulos, N., Mulller, K., Querol, X., Rodriguez, S., Schneider, J., Spindler, G., ten Brink, H., Torseth, K., and Wiedensohler, A.: European aerosol phenomenology-2: chemical characteristics of particulate matter at kerbside, urban, rural and background sites in Europe, Atmos. Environ., 38, 2579-2595, 2004.

Ramanathan, V.: The role of ocean-atmosphere interactions in the CO2 climate problem, J. Atmos. Sci., 38, 918-930, 1981.

Ramanathan, V. and Carmichael, G.: Global and regional climate changes due to black carbon, Nature Geosci., 1, 221-227, doi: 10.1038/ngeo156, 2008.

Schaap, M., Van Der Gon, H., Dentener, F. J., Visschedijk, A. J. H., Van Loon, M., ten Brink, H. M., Putaud, J. P., Guillaume, B., Liousse, C., and Builtjes, P. J. H.: Anthropogenic black carbon and 
fine aerosol distribution over Europe, J. Geophys. Res.-Atmos., 109, D18207, doi:10.1029/2003JD004330, 2004.

Schwarz, J. P., Stark, H., Spackman, J. R., Ryerson, T. B., Peischl, J., Swartz, W. H., Gao, R. S., Watts, L. A., and Fahey, D. W.: Heating rates and surface dimming due to black carbon aerosol absorption associated with a major US city, Geophys. Res. Lett., 36, L15807, doi:10.1029/2009GL039213, 2009.

Schwarz, J. P., Spackman, J. R., Gao, R. S., Perring, a. E., Cross, E., Onasch, T. B., Ahern, a., Wrobel, W., Davidovits, P., Olfert, J., Dubey, M. K., Mazzoleni, C., and Fahey, D. W.: The Detection Efficiency of the Single Particle Soot Photometer, Aerosol Sci. Technol., 44, 612-628, doi:10.1080/02786826. 2010.481298, 2010.

Schwarz, J. P., Gao, R. S., Fahey, D. W., Thomson, D. S., Watts, L. A., Wilson, J. C., Reeves, J. M., Darbeheshti, M., Baumgardner, D. G., Kok, G. L., Chung, S. H., Schulz, M., Hendricks, J., Lauer, A., Kaercher, B., Slowik, J. G., Rosenlof, K. H., Thompson, T. L., Langford, A. O., Loewenstein, M., and Aikin, K. C.: Single-particle measurements of midlatitude black carbon and light-scattering aerosols from the boundary layer to the lower stratosphere, J. Geophys. Res.-Atmos., 111, D16207, doi: 10.1029/2006JD007076, 2006

Schwarz, J. P., Gao, R. S., Spackman, J. R., Watts, L. A., Thomson, D. S., Fahey, D. W., Ryerson, T. B., Peischl, J., Holloway, J. S., Trainer, M., Frost, G. J., Baynard, T., Lack, D. A., de Gouw, J. A., Warneke, C., and Del Negro, L. A.: Measurement of the mixing state, mass, and optical size of individual black carbon particles in urban and biomass burning emissions, Geophys. Res. Lett., 35, L13810, doi:10.1029/2008GL033968, 2008a.

Schwarz, J. P., Spackman, J. R., Fahey, D. W., Gao, R. S., Lohmann, U., Stier, P., Watts, L. A., Thomson, D. S., Lack, D. A., Pfister, L., Mahoney, M. J., Baumgardner, D., Wilson, J. C., and Reeves, J. M.: Coatings and their enhancement of black carbon light absorption in the tropical atmosphere, J. Geophys. Res.-Atmos., 113, D03203, doi:10.1029/2007JD009042, 2008b.

Seinfeld, J. H. and Pandis, S. N.: Atmospheric chemistry and physics : from air pollution to climate change, Wiley, Hoboken, NJ, USA, 2nd edn., 2006.

Shiraiwa, M., Kondo, Y., Moteki, N., Takegawa, N., Miyazaki, Y., and Blake, D. R.: Evolution of mixing state of black carbon in polluted air from Tokyo, Geophys. Res. Lett., 34, L16803, doi: 10.1029/2007GL029819, 2007.

Shiraiwa, M., Kondo, Y., Moteki, N., Takegawa, N., Sahu, L. K., Takami, A., Hatakeyama, S., Yonemura, S., and Blake, D. R.: Radiative impact of mixing state of black carbon aerosol in Asian outflow, J. Geophys. Res.-Atmos., 113, D24210, doi:10.1029/ 2008JD010546, 2008.

Slowik, J. G., Cross, E. S., Han, J.-H., Davidovits, P., Onasch, T. B., Jayne, J. T., WilliamS, L. R., Canagaratna, M. R., Worsnop, D. R., Chakrabarty, R. K., Moosmueller, H., Arnott, W. P., Schwarz, J. P., Gao, R.-S., Fahey, D. W., Kok, G. L., and Petzold, A.: An inter-comparison of instruments measuring black carbon content of soot particles, Aerosol Sci. Technol., 41, 295314, doi:10.1080/02786820701197078, 2007.
Spackman, J. R., Schwarz, J. P., Gao, R. S., Watts, L. A., Thomson, D. S., Fahey, D. W., Holloway, J. S., de Gouw, J. A., Trainer, M., and Ryerson, T. B.: Empirical correlations between black carbon aerosol and carbon monoxide in the lower and middle troposphere, Geophys. Res. Lett., 35, L19816, doi:10.1029/2008GL035237, 2008.

Steinbacher, M., Zellweger, C., Schwarzenbach, B., Bugmann, S., Buchmann, B., Ordóñez, C., Prevot, a. S. H., and Hueglin, C.: Nitrogen oxide measurements at rural sites in Switzerland: Bias of conventional measurement techniques, J. Geophys. Res., 112, 1-13, doi:10.1029/2006JD007971, 2007.

Stephens, M., Turner, N., and Sandberg, J.: Particle identification by laser-induced incandescence in a solid-state laser cavity, Appl. Optics, 42, 3726-3736, 2003.

Stohl, A., Forster, C., Huntrieser, H., Mannstein, H., McMillan, W. W., Petzold, A., Schlager, H., and Weinzierl, B.: Aircraft measurements over Europe of an air pollution plume from Southeast Asia - aerosol and chemical characterization, Atmos. Chem. Phys., 7, 913-937, doi:10.5194/acp-7-913-2007, 2007.

Subramanian, R., Roden, C. A., Boparai, P., and Bond, T. C.: Yellow beads and missing particles: Trouble ahead for filter-based absorption measurements, Aerosol Sci. Technol., 41, 630-637, 2007.

Subramanian, R., Kok, G. L., Baumgardner, D., Clarke, A., Shinozuka, Y., Campos, T. L., Heizer, C. G., Stephens, B. B., de Foy, B., Voss, P. B., and Zaveri, R. A.: Black carbon over Mexico: the effect of atmospheric transport on mixing state, mass absorption cross-section, and BC/CO ratios, Atmos. Chem. Phys., 10, 219237, doi:10.5194/acp-10-219-2010, 2010.

Tsyro, S., Simpson, D., Tarrason, L., Klimont, Z., Kupiainen, K., Pio, C., and Yttri, K. E.: Modeling of elemental carbon over Europe, J. Geophys. Res.-Atmos., 112, 2007.

Vignati, E., Karl, M., Krol, M., Wilson, J., Stier, P., and Cavalli, F.: Sources of uncertainties in modelling black carbon at the global scale, Atmos. Chem. Phys., 10, 2595-2611, doi:10.5194/acp-102595-2010, 2010.

Virkkula, A., Ahlquist, N. C., Covert, D. S., Arnott, W. P., Sheridan, P. J., Quinn, P. K., and Coffman, D. J.: Modification, calibration and a field test of an instrument for measuring light absorption by particles, Aerosol Sci. Technol., 39, 68-83, 2005.

Virkkula, A.: Correction of the Calibration of the 3-wavelength Particle Soot Absorption Photometer ( $3 \lambda$ PSAP), Aerosol Sci. Technol., 44, 706-712, doi:10.1080/02786826.2010.482110, 2010.

Watson, J. G., Chow, J. C., and Antony Chen, L.-W.: Summary of organic and elemental/black carbon analysis methods and intercomparisons, Aerosol Air Quality Res., 5, 65-102, 2005.

Weingartner, E., Saathoff, H., Schnaiter, M., Streit, N., Bitnar, B., and Baltensperger, U.: Absorption of light by soot particles: determination of the absorption coefficient by means of aethalometers, J. Aerosol Sci., 34, 1445-1463, 2003. 